\title{
Rethinking Lohr: Does "SE" Mean Safe and Effective, Substantially Equivalent, or Both?
}

\section{Ralph F. Hall* \& Michelle Mercer**}

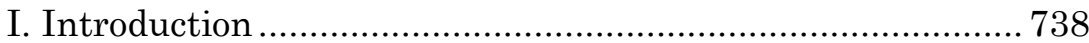

II. Background ...................................................................... 743

A. Development of Medical Device Regulation........................ 743

1. Medical Device Amendments of 1976 .................. 745

2. Safe Medical Device Act of 1990 ........................ 747

3. FDA Modernization Act.................................... 750

4. Medical Device User Fee and Modernization

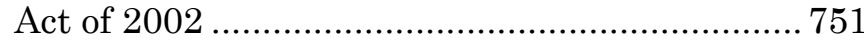

B. Current Methods for Reaching Market................... 751

1. Braving the Premarket Approval Process .......... 752

2. Reaching Market Through a Showing of

Substantial Equivalence Under $\S 510(\mathrm{k})$..........753

C. Preemption in the Medical Device Context. .............. 755

1. Federal Preemption of State Claim Under $\S$ 360k of the FDCA .............................................. 755

2. Court Analysis in Medtronic v. Lohr..................756

3. History of the Pacemaker Lead in Dispute......... 757

D. Holding in Riegel v. Medtronic, Inc......................... 759

E. Prominent FDA Preemption Decisions After

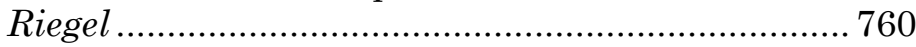

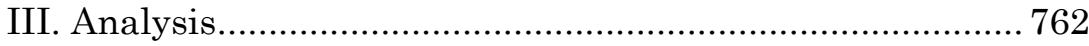

A. Summary of Preemption Elements Under $§ 360 \mathrm{k}$

and Relevant Supreme Court Precedent ............... 762

1. Required Preemption Elements .......................... 763

2. Understanding the Meaning of "Different

from" and "in Addition to"................................. 765

\footnotetext{
(C) 2012 Ralph F. Hall \& Michelle Mercer

* J.D., Distinguished Professor and Practitioner at the University of Minnesota Law School, Counsel to Faegre Baker Daniels, and CEO of MR3 Medical, L.L.C.

**J.D. The University of Minnesota Law School, 2012.
} 
3. If Modifications Require FDA Approval, Preemption Exists ... .767

B. Preemption Under $\S 360 \mathrm{k}$ - and Why Lohr Does

Not Apply to Current 510(k) Products................... 770

C. Impact of the Safe Medical Device Act of 1990 ......... 771

D. 510(k) Assessment of Safety and effectiveness:

Opinions of the FDA ............................................. 772

1. The FDA Asserts That it is Making Safety and Effectiveness Determinations for 510(k) Devices

2. FDA's Assessment of the 510(k) System

Deserves Deference 778

E. Certain (but Certainly Not All) Third Parties Also

Believe 510(k) Clearances Undergo a Safety and

effectiveness Assessment. 779

1. Institute of Medicine Is Critical of the 510(k)

System. 780

2. Industry Views

3. Other Critics and Voices.....

F. Recent 510(k) Clearances Demonstrate an

Assessment of Safety and Effectiveness 785

G. What Does a Safety and Effectiveness

Determination Mean for Lohr? 787

\section{INTRODUCTION}

Cases, even Supreme Court cases, interpreting statutes have precedential value until there are subsequent material changes in the statute. At that point, the case law must be reassessed to determine whether the changes in the statute impact the court's statutory analysis. One should not blindly follow a case interpreting a statute without considering whether the statute has been changed and, if so, the impact of any such change.

This article deals with one such situation in the area of medical device regulation and product liability preemption. ${ }^{1}$

1. We do not address whether preemption is good public policy or not. We leave that debate to others. Rather, we argue that the Food Drug \& Cosmetic Act and Supreme Court authority must be applied consistently. Those that believe preemption should be expanded or contracted should address their 
This article questions whether litigants and courts have ignored major statutory and regulatory changes in the FDA's authority over medical devices and have too simplistically followed the Supreme Court's decision in Medtronic, Inc. v. Lohr. ${ }^{2}$ We believe that this is exactly the situation and that the precedential value of Lohr is highly questionable.

At the forefront of technological innovation is the medical device industry. Because of the rapid evolution of science, technology, and the health care system, the regulatory framework governing medical devices changes frequently. As is expected, the provisions of the Food Drug and Cosmetic Act (FDCA) regulating medical devices have evolved substantially since $1938 .{ }^{3}$

Under the FDCA, as amended, the Food and Drug Administration (FDA) is responsible for ensuring that there is a "reasonable assurance of the safety and effectiveness of devices intended for human use." 4 As described in more detail below, to achieve the twin objectives of safety and effectiveness, Congress created three classes of medical devices based on risk. ${ }^{5}$ High risk, or Class III products, generally must obtain premarket approval from the FDA though the Pre-Market Approval (PMA) process. ${ }^{6}$ Medium risk products, or Class II products, generally have a different pathway to market - the $510(\mathrm{k})$ system. ${ }^{7}$ Compared to the PMA system, the $510(\mathrm{k})$ system of the FDCA creates a quicker and less expensive route for medical devices to reach the market. ${ }^{8}$ Under $\S 510(\mathrm{k})$, a product is cleared for market distribution if it is "substantially equivalent" to another device that has been cleared through the $510(\mathrm{k})$ process, a legally marketed pre-amendment device that does not require a PMA, a device type that has been down-

concerns to Congress.

2. Medtronic, Inc. v. Lohr, 518 U.S. 470 (1996).

3. See Food, Drug and Cosmetic Act, 21 U.S.C. $\S \S 301-399$ (2006), for the up-to-date version of the Act.

4. 21 U.S.C. $\S 393(b)(2)(C)(2006)$.

5. 21 U.S.C. $\S 360$ c(a) (2006). Other sections of $\S 360$ c set forth the classification and reclassification process.

6. Id. See 21 U.S.C. $\S 360$ e for a description of the PMA process.

7. The $510(\mathrm{k})$ process is described generally in 21 U.S.C. $§ 360 c$. We recognize that some lower risk Class III devices are regulated under the $510(\mathrm{k})$ system, some higher risk Class II products are required to go through the PMA process, and some higher risk Class I products require a $510(\mathrm{k})$. For our purpose these exceptions are not relevant to our analysis.

8. See 21 U.S.C. $§ 360 c(i)$ (detailing the substantial equivalence requirements) 
classified from class III/PMA or to one that has been classified through the de novo petition process into the $510(\mathrm{k})$ system. ${ }^{9}$ Section $510(\mathrm{k})$ is widely employed by medical device manufacturers and is responsible for many of the medical devices currently on the market. While yearly numbers vary, recently there have been approximately forty to fifty original PMAs, 1400 supplemental PMAs and 3 to $4000510(\mathrm{k}) \mathrm{s}$ received per year. ${ }^{10}$ Class I devices are the lowest risk devices and generally do not require any premarket authorization or clearance from the FDA. 11

Beginning in 2009, the $510(\mathrm{k})$ process has been under intensive review for a number of reasons. First, there was a highly public controversy involving the $510(\mathrm{k})$ clearance and then rescission of the $510(\mathrm{k})$ substantial equivalence decision by FDA of ReGen Menaflex, a medical device. ${ }^{12}$ The ReGen Menaflex scandal together with some other highly public product issues led to allegations that the $510(\mathrm{k})$ process fails to protect patients. ${ }^{13}$ Second, a number of commentators and the FDA itself concluded that it was time for a reassessment of the $510(\mathrm{k})$ system, at least in part, due to the ever increasing complexity of medical devices and the perceived aging of the $510(\mathrm{k})$ system. In fact, in 2009, the FDA commenced a detailed assessment of the $510(\mathrm{k})$ process. ${ }^{14}$ Third, a new administration

9. Id.

10. Food \& Drug Admin., Performance Report to Congress For the Medical Device User Fee Amendments of 2007, at 6, 20 (2009); OFF. OF Device Evaluation, Annual Performance Report 7 (2009). Note that the number of original PMAs cannot be directly compared to the number of $510(\mathrm{k}) \mathrm{s}$ (as some commentators have tried to do) because a change in a PMA product may go through the supplemental PMA process while a change in a $510(\mathrm{k})$ product triggers a new $510(\mathrm{k})$. There is no "supplemental" $510(\mathrm{k})$ analogous to the supplemental PMA process.

11. See 21 U.S.C. $\S 360$ c.

12. See generally FoOD \& DRUG ADMIN., REVIEW OF THE REGEN Menaflex: Departures from Processes, Procedures, and Practices LEAVE THE BASIS FOR REVIEW DECISION IN QUESTION-PRELIMINARY REPORT (2009) (finding multiple departures from process, procedure and practices over a seventeen year period).

13. FDA Questions Data Supporting Regen's Menaflex Ahead of 510(k) ReReview, MED. DEVICES TODAY (Mar. 24, 2010, 5:17AM), http://www.medicaldevicestoday.com/2010/03/fda-questions-data-supportingregens-menaflex-ahead-of-510k-rereview-.html.

14. Detailed information about the FDA's assessment of the $510(\mathrm{k})$ system and plan of action can be found at CDRH Plan of Action for $510(\mathrm{k})$ and Sci-
ence,
U.S.
FOOD
$\&$
DRUG
ADMIN., 
has taken the reins at the FDA. Given the 510(k) process's important role in medical device use and development, it was considered imperative to assess whether the current statutory system ensures that 510(k) medical devices are both substantially equivalent and safe and effective for their intended uses. ${ }^{15}$

Separately, two landmark Supreme Court cases have explored the difference between medical devices cleared via the $510(\mathrm{k})$ system and those approved under the PMA process. ${ }^{16}$ The two cases delved into the role FDA safety and effectiveness determinations play in product liability suits. These cases arise in situations in which the manufacturer/defendant has asserted that the plaintiff's claims are preempted under 21 U.S.C. $\S$ $360 \mathrm{k} .{ }^{17}$ Section $360 \mathrm{k}$ preempts any state law requirement (including a jury verdict) that is "different from, or in addition to," a safety and effectiveness determination made by FDA. 18

In Medtronic, Inc. v. Lohr, the Court ruled for the plaintiff Lora Lohr, and it held that the FDA did not assess the safety and effectiveness of the $510(\mathrm{k})$ medical device at issue in that case as part of the $510(\mathrm{k})$ clearance process. ${ }^{19}$ The $510(\mathrm{k})$ process, the Court concluded, only focuses on the medical device's equivalence to another device, not the device's safety and effectiveness. ${ }^{20}$ Therefore, the Court concluded that state law product liability claims against 510(k) devices are not preempted under $\S 360 \mathrm{k}$.

Roughly eleven years later, the Supreme Court heard a

http://www.fda.gov/AboutFDA/CentersOffices/OfficeofMedicalProductsandTob acco/CDRH/CDRHReports/ucm239448.htm (last visited Mar. 23, 2012). Details of the issues and proposed changes are generally outside of the scope of this Article.

15. Inst. OF Med., Public Health Effectiveness of the FDA 510(K) Clearance PRocess: BALANCING PATIENT SAFETY AND INNOVATIONWORKSHOP REPORT 1 (Theresa Wizemann, ed. 2010) [hereinafter October Report], available at http://www.iom.edu/Reports/2010/Public-HealthEffectiveness-of-the-FDA-510k-Clearance-Process-Balancing-Patient-Safetyand-Innovation.aspx.

16. See Riegel v. Medtronic, Inc., 552 U.S. 312 (2008); Medtronic, Inc. v. Lohr, 518 U.S. 470 (1996).

17. A finding of preemption generally precludes a judge or jury (federal or state) from finding liability against the defendant under common product liability theories. There are situations in which the plaintiff can prevail even if there is preemption. These include the "parallel claim" situations articulated by Justice Scalia in Riegel, 552 U.S. at 313.

18. 21 U.S.C. $\S 360 \mathrm{k}(\mathrm{a})(2006)$.

19. Lohr, 518 U.S. 470.

20. Id. at 493 . 
similar case yet ruled instead for Defendant Medtronic. ${ }^{21}$ In Riegel v. Medtronic, the Court found that the FDA made clear safety and effectiveness findings for devices approved through the PMA process. ${ }^{22}$ Medtronic's medical device in Riegelwhich was approved through a PMA and not a 510(k) - was found to be covered by the preemption provisions of $\S 360 \mathrm{k} .{ }^{23}$ Therefore, the state law product liability claims asserted against PMA medical devices are preempted by federal law.

Since these two cases, courts have generally found preemption for medical devices approved under the PMA process and have refused to find preemption for medical devices cleared through the $510(\mathrm{k})$ process. ${ }^{24}$

This article seeks to show that the statutory analysis in Lohr is outdated and no longer applicable in product liability suits against $510(\mathrm{k})$ medical devices due to material and significant statutory and regulatory changes in the $510(\mathrm{k})$ system since the relevant date in Lohr. Because the FDA now makes a determination of safety and effectiveness under the revised and updated $510(\mathrm{k})$ clearance process, the core logic of Lohr is no longer applicable. ${ }^{25}$ Part II of this Article provides a brief history surrounding the introduction of medical devices through the PMA process and the $510(\mathrm{k})$ "substantially equivalent" standard. In particular, Part II focuses on two landmark cases, Lohr and Riegel, and the role of each case in medical device product liability suits. Part III of this Article then provides a different interpretation to the arguments relied on in Lohr, in light of a changing statutory framework. Part III also shows that FDA itself (and some, but certainly not all interested stakeholders) asserts that the $510(\mathrm{k})$ system does assess safety and effective-

21. See Riegel, 552 U.S. at 312.

22. The PMA process is the most burdensome way for a medical device to reach market. The PMA process requires an assessment that the medical device at issue is both safe and effective. See 21 U.S.C. § 360e(c)(1)(A) (2006).

23. Riegel, 552 U.S. at 330.

24. See, e.g., Lake v. TPLC., 1 F. Supp. 2d 84, 86 (D. Mass. 1998); Dow v. Baxter Healthcare Corp., 899 F. Supp. 822, 823 (D. Mass. 1995).

25. In practice, the question of whether there is preemption in a specific $510(\mathrm{k})$ case will depend on the statutory system under which the product was cleared. Of course, cases involving products cleared under the $510(\mathrm{k})$ system in place at the relevant time period of Lohr are still governed by Lohr. Products cleared under later iterations of the $510(\mathrm{k})$ process should be assessed under those systems. For purposes of this article, we are looking at the two end points of the spectrum - the $510(\mathrm{k})$ system as it existed in 1982 (the critical date in Lohr) and today's 510(k) system. 
ness for $510(\mathrm{k})$ devices.

Ultimately, this article makes two conclusions. First, Lohr is not applicable to products cleared under the 2012 iteration of the $510(\mathrm{k})$ system. Second, the current $510(\mathrm{k})$ system, $\S 360 \mathrm{k}$, and the rationale of Riegel suggest that-due to the safety and effectiveness findings for $510(\mathrm{k})$ cleared devices-the standard relied upon in Riegel should supersede that of Lohr for products cleared under today's $510(\mathrm{k})$ system.

\section{BACKGROUND}

\section{A. DEVELOPMENT OF MEDICAL DEVICE REGULATION}

Early medical devices did not present complex or serious patient risks. Medical devices circa 1906 (the date of the original passage of the Pure Food and Drug Act) were essentially acute use products that worked by obvious and simple mechanical processes. ${ }^{26}$ Crutches, scalpels, bed pans, syringes, and bandages had obvious uses and simple requirements. The general adulteration and misbranding provisions of the Pure Food and Drug Act applied to devices and provided ample protection for patients. Even as late as 1938 (the date of the passage of the Food Drug and Cosmetic Act), medical devices were still generally simple mechanical devices. ${ }^{27}$ Because at this time devices also fit the statutory definition of a "drug," 28 the FDA could use its general adulteration and misbranding provisions ${ }^{29}$ to address unsafe products or labeling issues. There was no perceived need for a device premarket review system or other device specific requirements.

Beginning in the 1960s, there was increasing attention on the need to enhance the regulatory oversight of medical devices. ${ }^{30}$ Various proposals were floated. Perhaps the best known and most important were the proposals set forth in the so-

26. Pure Food and Drug Act of 1906, ch. 3915, §1, 34 Stat. 768 (repealed 1938). See generally FOOD \& DRUG ADMIN. A CENTURY OF CONSUMER Protection (Wayne L. Pines ed. 2006).

27. Food Drug and Cosmetic Act of 1938, Pub. L. No. 75-717, 52 Stat. 1040 (codified as amended at 21 U.S.C. $§ \S 321$ to 399D (2006)). See generally FooD \& DRUG ADMIN., supra note 26.

28. 21 U.S.C. $§ 321$ (g) (2006); see also United States v. An Article of Drug . . . Bacto-Unidisk, 89 S. Ct. 1410 (1969).

29. 21 U.S.C. $\$ \S 351-352$ (2006).

30. Peter B. HutT ET AL., Food AND Drug LaW 977 (3d ed. 2007). 
called Cooper Commission report. 31 The Commission was created in the late 1960s and charged with advising policy makers about improvements to the device regulatory system. ${ }^{32}$ The Cooper Commission proposed the core risk-based approach to device regulation used today. Congress did not create specific device centric requirements until the passage of the 1976 Medical Device Amendments (MDA). The MDA adopted a risk-based approach designed to achieve a core statutory objectiveproviding a reasonable assurance that medical devices are safe and effective. ${ }^{33}$

Congress recognized that it would take some time for the FDA to implement this system. In the meantime, new devices were constantly being brought to the market. Congress did not want to stifle the introduction of new products or give companies that got their products on the market immediately before the passage of the 1976 MDA a monopoly while the new system was being implemented. 34 To address these concerns, Congress enacted $\S 510(\mathrm{k}) .{ }^{35}$ Under this section, one could market a device that was substantially equivalent to a product marketed before the effective date of the MDA. ${ }^{36}$ Congress also authorized the FDA to create device centric performance standards for $510(\mathrm{k})$ products to ensure product safety and effectiveness. ${ }^{37}$

Over time, Congress, the FDA, and stakeholders recognized that performance standards were too confining, too hard to develop, and could not address changing technology. Stakeholders also recognized that the PMA process was too long and complex and did not add value or enhance the safety of a large number of medium risk products. Further, unlike drugs, medi-

\footnotetext{
31. Id. at $977-80$.

32. $I d$

33. 21 U.S.C. $§ 393(b)(2)(C)(2006)$.

34. For a general background to the 1976 Medical Device Amendments, see October Report, supra note 15, at 3-6. See generally FoOD \& DRUG ADMIN., supra note 26.

35. Medical Device Amendments of 1976, Pub. L. No. 94-295, 90 Stat. 539.

36. Note that substantial equivalence does not mean being identical. The standard is something that is more than similar but less than identical. For a more thorough definition of "substantial equivalence," see Premarket Notification (510k), U.S. FOOD \& DRUG ADMIN., http://www.fda.gov/ MedicalDevices/DeviceRegulationandGuidance/HowtoMarketYourDevice/Pre marketSubmissions/PremarketNotification510k/default.htm (last updated Sept. 3, 2010).
}

37. Cf. id. 
cal devices evolve in a fast paced, iterative pattern. Congress concluded that the medical device regulatory system needed to be updated and improved in order to enhance product safety and effectiveness. The result was the Safe Medical Devices Act of 1990 (SMDA). ${ }^{38}$ This was followed by the 1997 enactment of the FDA Modernization Act (often referred to as FDAMA) ${ }^{39}$ and then the 2002 enactment of the Medical Device User Fee and Modernization Act (MDUFMA). ${ }^{40}$ These various statutory enactments substantially enhanced and further expanded the FDA's regulatory control over medical devices to better ensure their safety and effectiveness.

\section{Medical Device Amendments of 1976}

The original FDCA granted the FDA specific authority over medical devices. ${ }^{41}$ In 1976 the Medical Device Amendments were adopted as a response to an increasing complexity, importance, and prevalence of medical devices on the market. ${ }^{42} \mathrm{~A}$ key feature of the 1976 Amendments was FDA classification of medical devices into three categories of regulatory controls: Class I, Class II, and Class III. ${ }^{43}$ Each device, whether classified as Class I, II, or III, is subject to general controls ${ }^{44}$ or the equivalence thereof. 45 "Controls" are regulatory measures necessary to assure the safety and effectiveness of the device. ${ }^{46}$

Simple devices (so-called Class I devices) are subject to on-

38. Safe Medical Devices Act of 1990, Pub. L. No. 101-629, 104 Stat. 4511. See generally FOOD \& DRUG ADMIN., supra note 26.

39. Food and Drug Administration Modernization Act of 1997, Pub. L. No. 105-115, 111 Stat. 2296.

40. Medical Device User Fee and Modernization Act of 2002, Pub. L. No. 107-250, 116 Stat. 1588.

41. Prior to 1976, medical devices were regulated under the general adulteration and misbranding provisions of the FDCA (21 U.S.C. $\S \S 351$ and 352 respectively). In some cases, the FDA regulated medical devices under the drug provisions of the FDCA. See United States v. An Article of Drug . . . Bacto-Unidisk ..., (1969).

42. See October Report, supra note 15, at 3-6.

43. 21 U.S.C. $\S 360$ c (2006).

44. General controls can include registration and listing requirements, compliance with quality system regulations (the so-called QSR requirements generally found in 21 C.F.R. $\S 820$ (2011)), and post market reporting obligations. See 21 U.S.C. $§ 360 c(a)$ for a more detailed description of general controls.

45. 21 U.S.C. $\S 360 c$.

46. Id.; see also Device Classification, U.S. FoOD \& DRUG ADMIN. (Apr. 27, 2009), http://www.fda.gov/MedicalDevices/DeviceRegulationandGuidance/ Overview/ClassifyYourDevice/default.htm. 
[Vol. 13:2

ly general controls. Devices in Class I do not "present a potential unreasonable risk of illness or injury" 47 and therefore are deemed to have a reasonable assurance of safety and effectiveness provided that they satisfy general controls. ${ }^{48}$ No premarket review by the FDA is required prior to distribution. ${ }^{49}$ An example of a Class I device is an examination glove or elastic bandage.

General controls were not, by themselves, considered sufficient to provide a reasonable assurance of safety and effectiveness for higher risk devices. Medium risk devices (Class II devices) were covered by performance standards and also by the general controls of the type covering Class I devices. 50 The original structure of the $510(\mathrm{k})$ system did not include many of the hallmarks of the current $510(\mathrm{k})$ system. For example, special controls are a key element of the current $510(\mathrm{k})$ system but were not created until 1990. ${ }^{51}$ An example of a medium risk device is an infusion pump, which presents more risk and requires more safety measures than a Class I examination glove.

In addition to identifying classes for medical devices, the Medical Device Amendments also created a regulatory structure - $\$ 510(\mathrm{k})$-allowing many Class II, medium risk, post1976 devices to be cleared for marketing by demonstrating substantial equivalence to a device already on the market.52 The $510(\mathrm{k})$ system is in many ways a comparative system. ${ }^{53}$ The new device is compared to an existing $510(\mathrm{k})$ product (referred

\footnotetext{
47. 21 U.S.C. $\S 360 c(a)(1)(A)(i i)(I I)$.

48. 21 U.S.C. $\S 360 c(a)(1)(A)$.

49. Jay H. Geller, Medical Device Amendments of 1976-Major Features and Comparisons, 31 Food DRUG CosMETIC L.J. 424, 424-28 (1976).

50. 21 C.F.R. $\S 860.3$ (2011).

51. Safe Medical Devices Act of 1990, Pub. L. No. 101-629, 104 Stat. 4511.

52. In addition, a number of higher risk Class I devices are also regulated under the $510(\mathrm{k})$ system. Congress also created a number of transitional processes to use as the $510(\mathrm{k})$ and PMA systems were being created and implemented. In many cases, these transitional provisions were designed to cover products already on the market in 1976. These transitional provisions are not relevant to this discussion.
}

53. U.S. DEP'T OF HEALTH \& HUMAN SERVS. ET AL., DRAFT GUIDANCE FOR INDUSTRY AND FOOD AND DRUG ADMINISTRATION STAFF: THE 510(K) Program: EVAluating SUbSTANTIAL EQUivalence IN PREMARKET NotifiCATIONS [510(K)], at 6 (2011) [hereinafter DRAFT GUIDANCE], available at http://www.fda.gov/MedicalDevices/DeviceRegulationandGuidance/Guidan ceDocuments/ucm282958.htm. 
to as the "predicate" device). 54 The predicate has been determined to be safe and effective based on actual market use and other experience. If the new device is comparable to the predicate, then it is viewed as having the same acceptable safety profile. ${ }^{55}$ Substantial equivalence means the device has the same intended use as the predicate and generally has the same technological characteristics as the predicate device. ${ }^{56}$ If there are different technological characteristics and those technological differences do not raise different questions of safety and effectiveness, the device manufacturer must submit data demonstrating that the device is as safe and as effective as the predicate device. ${ }^{57}$ Substantial equivalence was to be interpreted narrowly in instances "where necessary to provide reasonable assurance of its safe and effective performance," but substantially equivalent did not refer to only devices that were "identical" to those already on the market.58.

High risk devices generally were to go through the PMA process-in essence a version of the new Drug Application (NDA) process created in 1962.59 These devices are ones for which both general and special controls are insufficient to assure the safety and effectiveness of the device. 60

Each level of control in the system was designed to provide the necessary oversight and reasonable assurance of safety and effectiveness. It was never the intent of Congress that some devices would have to have a "reasonable assurance" of safety and effectiveness while others would not need to meet this standard. The objectives did not vary. Rather Congress used different means to achieve that objective.

\section{Safe Medical Device Act of 1990}

The first major post-1976 reformation of the FDCA was the Safe Medical Device Act of 1990 (SMDA), which was adopted in response to concerns that devices were not being adequately regulated and in response to a number of mishaps in the medi-

54. Premarket Notification (510k), supra note 36. In a few cases not relevant to this discussion, so-called "pre-amendment" devices can serve as predicates.

55. See id.

56. 21 U.S.C. $§ 360 c(2006)$.

57. Id.

58. Medical Device Amendments of 1976, Pub. L. No. 94-295, §§ 514-515.

59. 21 U.S.C. $\S 355$ (2006).

60. 21 U.S.C. $\S 360$ c. 
cal device realm. ${ }^{61}$ The SMDA substantially expanded FDA authority over medical device regulation and increased burdens on manufacturers of medical devices. ${ }^{62}$ Specifically, the SMDA essentially rewrote the $510(\mathrm{k})$ process. 63 A comparison of the 1976 statute and the current statute can be found in Appendix A. From this comparison, one can see that the current statutory framework imposes more safety and effectiveness requirements on $510(\mathrm{k})$ medical devices.

First, the SMDA explicitly defined substantial equivalence and substantially increased the robustness of the $510(\mathrm{k})$ system as well as the regulatory use of "substantial equivalence." 64 Substantial equivalence now requires the device to have both the same intended use and the same technological characteristics as the predicate device. ${ }^{65}$ If there is a new intended use, the product is not eligible for clearance under the $510(\mathrm{k})$ system. ${ }^{66}$ Remember that the safety and effectiveness of the predicate is a key basis for concluding that the new device has a reasonable assurance of safety and effectiveness.

If the product is being used for a different purpose (a different disease for example) the comparison to the predicate is not sufficient to show safety and effectiveness depending upon the impact on safety and effectiveness, and therefore may be found to be not substantially equivalent. ${ }^{67}$ If there are different technological characteristics, the device manufacturer must submit data-including, as necessary, clinical data-

61. E.g., Russell Mokhiber, The Dalkon Shield: A Deadly Product from A.H. Robbins, 8 CORP. CRIME \& VIOLENCE (Apr. 1987), http://multinationalmonitor.org/hyper/issues/1987/04/ahrobins.html; see also Medtronic, Inc. v. Lohr, 518 U.S. 470, 476 (1996) (citing the Dalkon Shield as being one of several catastrophic events leading to the Safe Medical Device Act of 1990).

62. Ellen J. Flannery, The Safe Medical Devices Act of 1990: An Overview, 46 FOOD \& DRUG CosM. L.J 129, 129 (1991).

63. See id. at 131-33.

64. 21 U.S.C. $§ 360 c(2006)$.

65. Id. $\S 360 \mathrm{c}(\mathrm{i})$.

66. Id. A "denial" of a $510(\mathrm{k})$ submission is often referred to as a "not substantial equivalence" or "NSE" determination. See DRAFT GUIDANCE, supra note 53, at 4 . A product found to be NSE must either obtain a PMA approval under 21 U.S.C. $\$ 360$ e or, much less commonly, go through the "de novo" process under 21 U.S.C. $\$ 360 \mathrm{c}(\mathrm{f})$ and then, if it meets all regulatory requirements, be classified as $510(\mathrm{k})$ eligible and then be determined as substantially equivalent (or "SE").

67. 21 U.S.C. 360c(i). 
demonstrating that the device is as safe and as effective as the predicate device. ${ }^{68}$ Particularly, the statute specifically allows the FDA to request clinical data when the new device has technological changes as compared to the predicate device. ${ }^{69}$ If the new technolobical characteristics raise different questions of safety and effectiveness, the $510(\mathrm{k})$ for the device will be found to be not substantially equivalent.70

In addition, the SMDA added a new regulatory control mechanism. Medium risk devices were also now made subject to "special controls" because "the general controls by themselves are insufficient to provide reasonable assurance of the safety and effectiveness of the device." 71 Special controls can include the $510(\mathrm{k})$ clearance process, performance standards, clinical data, bench data, post market studies, and registries. ${ }^{72}$

After the SMDA, a device demonstrating substantial equivalence did not have to have a pre-1976 device as a predicate. Any manufacturer can receive $510(\mathrm{k})$ clearance, so long as the device is proven to be substantially equivalent to a $510(\mathrm{k})$ device already determined by the FDA to be substantially equivalent. ${ }^{73}$ After the SMDA, a predicate device could be a device cleared through the $510(\mathrm{k})$ process, a device that was marketed prior to May 28, 1976 (a pre-amendment device), or a device that was originally on the U.S. market as a Class III PMA device and later reclassified as a $510(\mathrm{k})$ device. ${ }^{74}$

Additionally, manufacturers of medical devices requiring $510(\mathrm{k})$ must submit either a $510(\mathrm{k})$ summary of safety and effectiveness data to be reviewed by FDA or a $510(\mathrm{k})$ statement. ${ }^{75}$

Another important change promulgated by the SMDA was the modification of pre-1976, Class III high risk devices regulation. The original 1976 Amendments directed the FDA to conduct premarket approvals for Class III devices already on the market after they had been classified by the agency for at least

68. $I d$.

69. $I d$.

70. 21 U.S.C. $§ 360 c(i)(1)(A)(i i)(2011)$.

71. Id. $\S 360 \mathrm{c}(\mathrm{a})(1)(\mathrm{B})$.

72. $I d$.

73. See Id. §360c(i) (“'[S]ubstantial equivalence' means, with respect to a device being compared to a predicate device ....."). Note that the language of the statute does not include a requirement that the predicate device be pre1976.

74. October Report, supra note 15 , at $82-84$.

75. Flannery, supra note 62 , at 149 . 
[Vol. 13:2

thirty months; 76 in reality, at that time, few premarket approvals were actually called for under $\S 515(\mathrm{~b})$ and performed for those devices. ${ }^{77}$ As a result, many pre-1976 Class III devices never completed a premarket approval and were never determined to be safe and effective. ${ }^{78}$ Thus, devices "substantially equivalent" to pre-1976 Class III devices were purported to be substantially equivalent in all respects, including safety and effectiveness of which there was no actual proof. ${ }^{9}$ The SMDA changed this. After enactment, the SMDA required manufactures of pre-1976 Class III device types still subject to $510(\mathrm{k})$ to submit a detailed summary including adverse data relating to the safety and effectiveness of the device type in their $510(\mathrm{k}) .80$ The FDA then was to consider whether to reclassify the pre1976 devices based on the level of regulation needed to provide a reasonable assurance of safety and effectiveness. ${ }^{81}$ If a product remained in Class III, the manufacturer was required to obtain a premarket approval for such devices. ${ }^{82}$ As a result, the SMDA substantially modified the 1976 system to better ensure the safety and effectiveness of all medical devices hitting the market after 1990. The Act demonstrates both Congress's and the FDA's increased focus on safety.

\section{FDA Modernization Act}

In 1997, Congress passed the FDA Modernization Act (FDAMA). This statute was intended to-among other purposes-better regulate medical devices and to ensure that there was an appropriate balance between safety and patient access to medical devices. ${ }^{83}$ FDAMA instituted a number of changes in medical device statutory regulation including the creation of "good guidance practices" (GGPs) and the enactment of the "least burdensome" principle. ${ }^{84}$ FDAMA further demonstrates

76. Medical Device Amendments of 1976, Pub. L. No. 94-295, § 515.

77. Flannery, supra note 62 , at 135.

78. Id.

79. See id.

80. Id.; see 21 U.S.C. § 360c(i) (2006).

81. Flannery, supra note 62 , at $135-36$.

82. 21 U.S.C. $\S 360 c(i)$.

83. See Food \& Drug Admin., OfFice of Device Evaluation \& CTR. For Biologics Evaluation \& Research, The Lease BuRdensome Provisions OF THE FDA MODERNIZATION ACT OF 1997: CONCEPT AND PRINCIPLES; FINAL GUIDANCE FOR FDA AND INDUSTRY 1 (2002).

84. Id. at 2 (defining the least burdensome principle as "a successful 
that Congress has exercised active oversight of the device regulatory system.

4. Medical Device User Fee and Modernization Act of 2002

In 2002, Congress enacted the Medical Device User Fee and Modernization Act Congress intended MDUFMA to give the FDA resources to "better review medical devices, to enact needed regulatory reforms so that medical device manufacturers can bring their safe and effective devices to the American people at an earlier time, and to ensure that reprocessed medical devices (those disposable devices reprocessed for another single use) are as safe and effective as original devices." 85 MDUFMA has since enabled the FDA to better assess medical devices, ensuring their safety and effectiveness. 86 The enactment of MDUFMA has allowed the FDA to place more time and resources towards medical device review. 87

\section{B. Current Methods for Reaching MARKeT 88}

Currently, a medical device has three methods of reaching market. First, most low risk/Class I devices, such as tongue depressors and many in vitro diagnostic devices, do not require any $510(\mathrm{k})$ clearance before market if they meet the criteria in section 510(l) of the FDCA and do not add a new use or new fundamental technology in comparison to the legally marketed Class I device type. ${ }^{89}$ General controls are considered adequate to provide reasonable assurance of the safety and effectiveness of Class I devices. ${ }^{90}$ Second, a high risk medical device (generally Class III) that has not been classified into Class I or Class II and whose risks and how to mitigate those risks are not under-

means of addressing a premarket issue that involves the most appropriate investment of time, effort, and resources on the part of industry and FDA"); see also 21 C.F.R. 10.115 (2012).

85. Background on MDUFMA, U.S. FOOD \& DRUG ADMIN., http://www.fda.gov/MedicalDevices/DeviceRegulationandGuidance/Overview/ MedicalDeviceUserFeeandModernizationActMDUFMA/ucm109149 (last updated Mar. 2, 2009).

86. $I d$.

87. Id.

88. Section B outlines the FDA's current process for medical device review; this is to be distinguished from Section A, which discussed the FDA review process as it stood in 1976. See Appendix A for a detailed table comparing the 1976 FDCA with the current FDCA.

89. 21 C.F.R. $§ 860.3(2011)$

90. Id. 
stood well enough to identify Special Controls to provide reasonable assurance of the safety and effectiveness of the device type, may reach market via the PMA route if the manufacturer can demonstrate to the FDA that their device is safe and effective for its intended use. ${ }^{91}$ Thirdly, a manufacturer can seek clearance via the $510(\mathrm{k})$ system for medium risk products/mostly Class II devices, by meeting all relevant regulatory requirements and by showing "substantial equivalence."92

\section{Braving the Premarket Approval Process}

The PMA process is a regulatory review specifically evaluating the safety and effectiveness of a specific medical device. ${ }^{93}$ Before a device manufacturer can market its Class III/PMA medical device, it must obtain FDA approval. ${ }^{94}$ The PMA process is the most rigorous process for a medical device to reach market. First, the manufacturer must complete the PMA application. ${ }^{95}$ The PMA application requires non-clinical laboratory studies and clinical investigations to be submitted to the FDA; both are time consuming and expensive. ${ }^{96}$ The studies must be sufficiently thorough to provide reasonable assurance that the device is safe and effective for the intended use. ${ }^{97}$

Once the application is submitted to the FDA, the device manufacturer must wait for review and approval before its device can be marketed. ${ }^{98}$ The time taken to respond to PMA applications is significantly longer compared to manufacturers

91. Id.

92. Clinical (or pre-market) studies of medical devices on human subjects are governed by the Investigational Device Exemption (IDE) process under 21 U.S.C. $\$ 360 \mathrm{e}(\mathrm{j})$ (2006). The IDE process requires FDA and Institutional Review Board approval of the clinical study to ensure patient protection (including safety) and the scientific value of the study. See also 21 C.F.R. $\S \S 50,54$, 312 (2011).

93. Premarket Approval (PMA), U.S. FOOD \& DRUG ADMIN., http://www.fda.gov/MedicalDevices/DeviceRegulationandGuidance/HowtoMar ketYourDevice/PremarketSubmissions/PremarketApprovalPMA/default.htm (last updated Jan. 24, 2012). PMAs are required for all Class III medical devices and some Class II devices.

94. Id. In addition to the statutory provisions, the FDA has enacted a number of implementing regulations. PMA regulations are generally found in 21 C.F.R. $\S 814$ (2011).

95. Premarket Approval (PMA), supra note 93.

96. See 21 C.F.R $\S 814.20$ (2011).

97. Id.

98. Premarket Approval (PMA), supra note 93. 
who seek clearance through a showing of substantial equivalence. For example, if a manufacturer submits a 510(k) it takes, on average, seventy-three days of FDA time for the FDA to make a decision ${ }^{99}$ compared to an several hundred days for a PMA. 100 Overall, the PMA process is more expensive and takes more time than clearance through $\S 510(\mathrm{k})$. For these reasons, manufacturers frequently attempt to gain FDA clearance under $510(\mathrm{k})$ rather than approval through a PMA if the device type has not already been classified as a PMA. 101

\section{Reaching Market Through a Showing of Substantial} Equivalence Under $§ 510(\mathrm{k})$

Class I and Class II devices that are not exempt from the $510(\mathrm{k})$ requirements of the FDCA must obtain 510(k) clearance before marketing. The actual statutory provisions governing the $510(\mathrm{k})$ process are complex and not susceptible to instant understanding. The $510(\mathrm{k})$ system has been built over time with Congress and the FDA adding new requirements or processes. 102

Establishing equivalence under $510(\mathrm{k})$ is faster, cheaper, and far less burdensome than the PMA process. In order to be classified as substantially equivalent, the device must pass

99. Ctr. for Devices \& Radiological Health, Analysis of Premarket Review Times Under the 510(k) Program, U.S. FOOD \& DRUG ADMIN. http://www.fda.gov/AboutFDA/CentersOffices/OfficeofMedicalProductsandTob acco/CDRH/CDRHReports/ucm263385.htm (last updated Nov. 09, 2011). Note that their time frames do not include the days spent by industry in responding to FDA questions.

100. GAO Confirms Total DeVICE Decision Times TAKIng Longer, FDA NOT MEETING SOME GOALS, U.S. GOV'T ACCOUNTABILITY OFFICE, http://www.coburn.senate.gov/public//index.cfm?a=Files.Serve\&File_id=9f722b 64-1d0d-4905-9efb-3b5b6871c145. Statutorily, the FDA must respond to PMA applications in 180 days after submission. 21 C.F.R. $\S 814.42$ (2011). In practice, however, the FDA takes much longer. For example, if an amendment to the application is submitted, the 180 day clock restarts. CTR. FOR DEVICES \& RADIOLOGICAL HEALTH, FDA AND INDUSTRY ACTIONS ON PREMARKET APPROVAL APPLICATIONS (PMAS): EFFECT ON FDA REVIEW CLOCK AND GOALS 7 (2008), available at http://www.fda.gov/downloads/MedicalDevices/Device RegulationandGuidance/GuidanceDocuments/ucm089734.pdf.

101. See October Report, supra note 15, at 9 (explaining that substantial equivalence "allow[s] products to go to market quickly with appropriate safeguards," which makes them an attractive option for device manufacturers).

102. As discussed earlier, key statutory changes occurred in 1976, 1990, 1997, and 2002. Lesser changes were made at different times. In addition, over time the FDA promulgated new regulations, guidance documents and standard operating procedures. 
through a series of checkpoints. ${ }^{103}$ First, the manufacturers must identify a legally marketed predicate device. Second, the manufacture must demonstrate that the device has the same intended use as the predicate device. ${ }^{104}$ If the device does not have the same intended use as its predicate, the device is "not substantially equivalent" (NSE) within the meaning of $\S 510(\mathrm{k}) .{ }^{105}$ Next, the medical device must have matching technological characteristics as the predicate device. ${ }^{106}$ If the technological characteristics are different from those of the predicate device in such a way that may have an effect the device's safety and effectiveness, the FDA will assess whether those differences in technology raise any safety and effectiveness concerns or questions. ${ }^{107}$ The product, if Class II, must also comply with all applicable special controls, including any mandatory performance standards. 108

The FDA is permitted by statute to request data from clinical trials demonstrating that the device is both as safe and as effective as the predicate device. ${ }^{109}$ The data also aids the FDA in its substantial equivalence determination. ${ }^{110}$

So long as no new type of safety and effectiveness questions are raised, the $510(\mathrm{k})$ submitter meets all regulatory requirements, and "accepted scientific methods [are available] for assessing the effects" of the device, the FDA will clear the device. ${ }^{111}$

One cannot simply talk about, or draw conclusions about,

103. An overview of the process and decision points can be found in various FDA guidance documents. For an example, see DRAFT GUIDANCE, supra note 53. A recent draft update to the 1998 guidance reiterates these decision points.

104. Benjamin A. Goldberger, Note, The Evolution of Substantial Equivalence in FDA's Premarket Review of Medical Devices, 56 FoOD \& DRUG L.J. 317, 323-24 (2001) (describing the process a device seeking clearance through $510 \mathrm{~K}$ must pass).

105. See id. at 324 .

106. Id.; see also Janice Hogan \& Gwyn Simmons, Standards for Clearance of 510K Premarket Notifications in the US, RAJ DEVICES, 311-12 (Sept./Oct. 2008), http://www.hoganlovells.com/files/Publication/c6c923f0-742a-4b63-be7aeb10fc689261/Presentation/PublicationAttachment/db563313-55cf-4519-9c8a-

1417ccd17afb/RAJ.pdf ("[T]echnological characteristics [may include] design, materials and energy sources ....").

107. Hogan \& Simmons, supra note 106, at 311-12.

108. 21 U.S.C. $\S \S 360 c(a), 360 d(2006)$.

109. 21 U.S.C. $\S 360 \mathrm{c}(\mathrm{i})(1)(\mathrm{A})$.

110. Id.

111. Goldberger, supra note 104 , at 324 . 
the $510(\mathrm{k})$ system as one system throughout time. Rather, one must consider the system as it existed at the time the particular 510(k) submission was reviewed by the FDA. Conclusions about the nature of the $510(\mathrm{k})$ system as it existed in 1982 may well not be applicable to the $510(\mathrm{k})$ system as it exists today. This, we contend, is the fundamental challenge with the rote citation to Lohr for the proposition that today's 510(k) system does not assess safety and effectiveness.

\section{Preemption in the Medical Device Context.}

\section{Federal Preemption of State Claim Under $\S 360 \mathrm{k}$ of the} FDCA

Preemption is the legal doctrine that federal requirements override similar state or local legal requirements. ${ }^{112}$ There are three general types of preemption. Express preemption requires an explicit Congressional enactment.113 In these cases, the statutory language and Congressional intent define the boundaries and parameters of preemption. ${ }^{114}$ Implied preemption exists in situations in which Congress has so occupied a specific subject that courts conclude that Congress intended federal law to be the sole set of requirements. ${ }^{115}$ Conflict preemption (also called impossibility preemption) exists when a person or entity cannot comply with both a federal requirement and a state requirement. ${ }^{116}$ If a person or entity literally cannot comply with both federal and state requirements, federal requirements predominate.

From the beginning of medical device regulation with the enactment of the Medical Device Amendments of 1976, Congress exercised its power under the Supremacy Clause and expressly preempted state-created medical device requirements.

Section $360 k(a)$ prohibits states from establishing device

112. See U.S. ConsT. art. VI, cl. 2 ("This Constitution, and the Laws of the United States which shall be made in Pursuance thereof; and all Treaties made, or which shall be made, under the Authority of the United States, shall be the supreme Law of the Land; and the Judges in every State shall be bound thereby, any Thing in the Constitution or Laws of any State to the Contrary notwithstanding.").

113. See Nanopierce Tech. v. Depository Trust \& Clearing Corp., 168 P.3d 73, 79 (Nev. 2007) ("Congress expressly preempts state law when it explicitly states that intent in a statute's language.").

114. See id.

115. Cipollone v. Liggett Group, Inc., 505 U.S. 504, 516 (1992).

116. Id. 
requirements additional to or different from those required by the FDA: Section $360 \mathrm{k}(\mathrm{a})$ reads:

(a) General rule. Except as provided in subsection (b), no State or political subdivision of a State may establish or continue in effect with respect to a device intended for human use any requirement-

(1) which is different from, or in addition to, any requirement applicable under this Act to the device, and

(2) which relates to the safety or effectiveness of the device or to any other matter included in a requirement applicable to the device under this Act. 117

This provision, enacted as a part of the 1976 Medical Device Amendments, preempts state claims which establish either additional requirements or different requirements relating to the safety and effectiveness of devices under the FDCA. FDA's implementing regulations limit preemption to situations in which the agency has device specific requirements and does not cover so-called "general requirements," such as zoning laws, building codes, and tax obligations. ${ }^{118}$ In essence, $\S 360 \mathrm{k}$ preempts any state court requirement, including court cases, which impose or seek to impose requirements on medical devices in situations in which the FDA has created or has the authority to create device specific requirements relating to safety and effectiveness.

While the Court in Lohr established that $\S 360 \mathrm{k}(\mathrm{a})$ "expressly preempts state law, "it acknowledged that $\S 360 \mathrm{k}(\mathrm{a})$ was not intended to preempt all state laws and regulations. ${ }^{119}$ The Court reasoned that "any understanding of the scope of a preemption statute must rest primarily on 'a fair understanding of congressional purpose."120 "Congress' intent, of course, primarily is discerned from the language of the pre-emption statute and the 'statutory framework' surrounding it."121

\section{Court Analysis in Medtronic v. Lohr}

The Supreme Court first applied preemption to medical devices under $\S 360 \mathrm{k}$ in 1996 in Medtronic, Inc. v. Lohr. The

117. 21 U.S.C. $\S 360 \mathrm{k}(\mathrm{a})(2006)$.

118. 21 C.F.R $\S 808.1(b)$, (d) (2011).

119. Medtronic, Inc. v. Lohr, 518 U.S. 470, 484 (1996); see 21 U.S.C. § $360 \mathrm{k}(\mathrm{a})$.

120. Lohr, 518 U.S. at 485-86 (quoting Cipollone, 505 U.S. at 530).

121. Id. at 486 (quoting Gade v. National Solid Wastes Management Ass'n, 505 U.S. 88, 111 (1992) (Kennedy, J., concurring in part and concurring in judgment)). 
device at issue in Lohr was the lead for a cardiac pacemaker-a wire responsible for carrying electric impulses or signals to and from the heart. ${ }^{122}$ Medtronic produced the pacemaker lead, and the FDA cleared it for distribution under the 510(k) process of the MDA. ${ }^{123}$ The device was cleared by the FDA in $1982 .{ }^{124}$ Due to an alleged defect in the lead, the pacemaker system failed several years after it was implanted.125 The plaintiffs sued Medtronic asserting common law product liability theories. ${ }^{126}$ Medtronic argued that the plaintiff's defective device claim was preempted under the FDCA, asserting that "federally enforceable design requirement[s] cannot be affected by state-law pressures such as those imposed on manufacturers subject to product liability suits." 127 The Court rejected this claim and ultimately held that, because the $510(\mathrm{k})$ process that was in place when the device was reviewed by the FDA does not focus on safety and effectiveness, but rather on equivalence, the plaintiff's defective device claim was not preempted by federal law. 128

\section{History of the Pacemaker Lead in Dispute}

The pacemaker system at the center of the Lohr dispute was a Model 8403 Activitrax with a Model 4011 lead.129 In 1980, Model 4011 leads were classified as Class III devices. ${ }^{130}$ Shortly thereafter, in 1982, Medtronic submitted an application to have a Model 4011 lead cleared through 510(k), claiming substantial equivalence to a pre-1976 device. ${ }^{131}$ Approximately one month later, the FDA allowed Medtronic to "market the Model 4011 lead subject only to the MDA's Class I general con-

122. Id. at 493 (ultimately determining that the $510 \mathrm{k}$ process does not assess the safety of the device, but just the device's equivalence to its predicate).

123. Id. at 474 .

124. Id. at 480 .

125. Id. at 474 .

126. Id. at 481 .

127. Id. at 492 .

128. Id. at 503 .

129. Mary Elizabeth Phelen, When a Pacemaker Or Other Medical Device Fails: Does Federal Law Deprive Those Injured of Their State Law Remedies?, 1995-1996 PREVIEW U.S. SUP. CT. CAS. 365, 366. A pacemaker lead "is a wire connected to the pacemaker that delivers the electrical impulse to the heart." Id.

130. Id.

131. See id. (demonstrating that, given the timeline, neither the preamendment pacemaker, nor the pacemaker cleared through the substantial equivalence process were ever reviewed for safety and effectiveness). 
trols applicable to all devices."132 Medtronic continued making leads, piggy-backing on predecessors and obtaining clearances through the $510(\mathrm{k})$ system. ${ }^{133}$ As summarized in a 1992 government report that reviewed multiple failures of Medtronic pacemakers, the FDA never determined Medtronic's 4011 leads to be either safe or effective. ${ }^{134} \mathrm{Ms}$. Lohr was implanted with Medtronic's pacemaker system using the 4011 lead in 1987.135

Medtronic's central defense in Lohr was an assertion of federal preemption under $\S 360 \mathrm{k}$ (a) of the FDCA. ${ }^{136}$ Medtronic asserted that Lohr's design claim was preempted because the FDA, by way of clearance under $510(\mathrm{k})$, already promulgated federally enforceable design requirements for Medtronic's pacemaker. ${ }^{137}$ Therefore, Medtronic argued, Lohr's action for negligent design was attempting to enforce an additional and contrary requirement to an FDA established requirement. ${ }^{138}$ In rejecting Medtronic's preemption argument, the Court concluded that the $510(\mathrm{k})$ process did not assess safety or efficacy of the device and that manufacturers entering the market under $510(\mathrm{k})$ clearance should expect "the possibility that [they will] have to defend [themselves] against state-law claims of negligent design." 139 Additionally, the Court found the "general controls" governing the pacemaker lead were not "specific requirements applicable to a particular device under the act," but instead were generic provisions that apply to all devices regulated under the FDCA. ${ }^{140}$

Given that the device in question was cleared by the FDA in 1982, the Court in Lohr only mentions the 1990 SMDA in

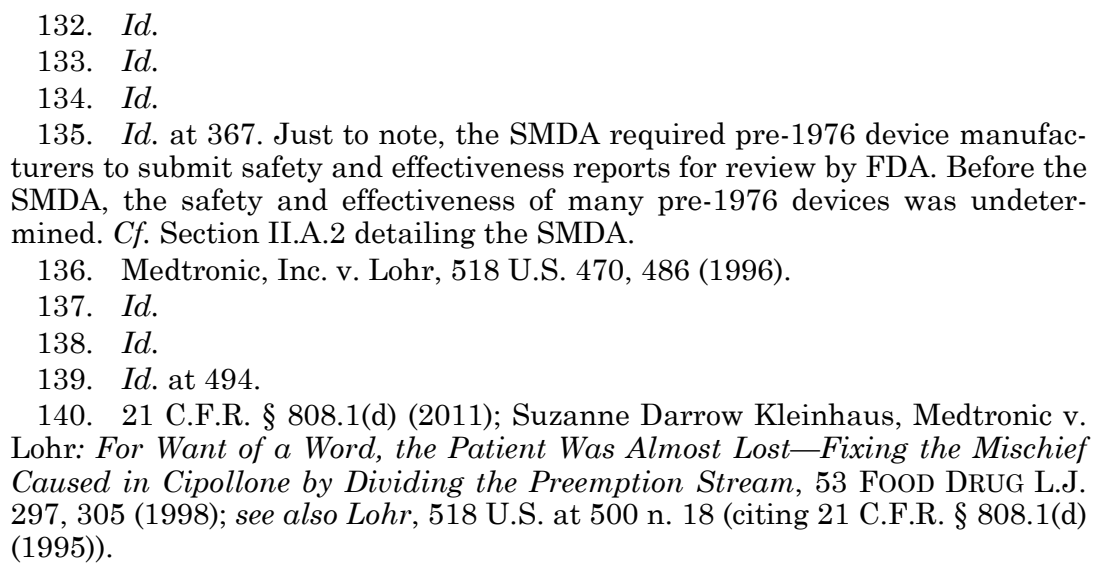
Lohr: For Want of a Word, the Patient Was Almost Lost-Fixing the Mischief Caused in Cipollone by Dividing the Preemption Stream, 53 FOOD DRUG L.J. 297, 305 (1998); see also Lohr, 518 U.S. at 500 n. 18 (citing 21 C.F.R. § 808.1(d) (1995)). 
passing and certainly does not analyze preemption under the post-SMDA regulatory system. Lohr left open the question of whether products going through the PMA process under 21 U.S.C. $\S 360 \mathrm{e}$ were entitled to preemption. This question was answered by the Supreme Court in 2008.

\section{Holding IN RIEGEL V. MEDTRONIC, INC.}

In 2008, the Supreme Court again applied preemption to a medical device product liability claim in Riegel $v$. Medtronic, Inc. ${ }^{141}$ The device at the center of the dispute in Riegel was an Evergreen Balloon Catheter used for an angioplasty procedure for Charles Riegel in 1999.142 The catheter was a Class III device and received FDA approval under the PMA process in 1994. ${ }^{143}$ The catheter's labeling specified that the catheter should not be used in patients with calcified stenosis. ${ }^{144} \mathrm{Mr}$. Riegel had calcified stenosis. ${ }^{145}$ Furthermore, the physician was instructed not to inflate the balloon beyond eight atmospheres of pressure. ${ }^{146}$ Contrary to what the label of the catheter instructed, Riegel's catheter was inflated five times to ten atmospheres-well above the recommended pressure. ${ }^{147}$ On the fifth time, the balloon burst, injuring Mr. Riegel.148 As a result, a heart block developed and emergency coronary bypass surgery was required. ${ }^{149} \mathrm{Mr}$. Riegel brought suit against Medtronic alleging design defects and labeling problems in violation of New

141. Riegel v. Medtronic, Inc., 552 U.S. 312 (2008).

142. Id. at 312 . Angioplasty is a procedure during which blocked coronary arteries are opened by inflating a balloon inside the arterial blockage thus forcing the artery open. The balloon is attached to a catheter and inserted into the appropriate coronary artery. The balloon is then inflated opening the artery. Once the artery is open, the catheter and attached balloon are removed. See What is Coronary Angioplasty?, NAT'L HEART LUNG \& BLOOD INST., http://www.nhlbi.nih.gov/health/health-topics/topics/angioplasty/ (last visited Apr. 4, 2012).

143. Riegel, 552 U.S. at 312. The Court described the PMA process as including, among many other facets, a thorough evaluation of the safety and effectiveness of the device. $I d$. at 318. The Court also noted that once a device is approved through PMA, the FDA "forbids . . . changes in design specifications . . or any other attribute...." Id. at 319 .

144. Id. at 320 .

145. Id.

146. Id.

147. Id.

148. Id.

149. Id. 
York common law. 150

In contrasting the facts of the situation in Riegel with those in Lohr, the Riegel Court found that "premarket approval is specific to individual devices" and "is focused on safety, not equivalence." 151 Since Mr. Riegel's product liability claims focused on the safety and effectiveness of the catheter, and the FDA already specified requirements for that same catheter, the Court concluded the New York common law imposed different or additional requirements on the device. ${ }^{152}$ The FDCA was thus found to preempt Riegel's claim for negligent design and faulty product labeling. ${ }^{153}$

\section{E. Prominent FDA Preemption Decisions After RiegeL}

In a recent Supreme Court case, Wyeth v. Levine, the Court again faced a question of federal preemption in a product liability suit. ${ }^{154}$ In Wyeth, the FDA approved drug-Phenerganpresented an increased risk of gangrene if used by injection rather than intravenous drip. ${ }^{155}$ Phenergan contained an adequate warning label per FDCA requirements; yet, when the plaintiff lost her arm due to gangrene, the FDCA was found not to preempt a state law product liability claim. ${ }^{156}$ At first blush, the holding in Wyeth seems contrary to the holding in Riegel. The key difference is that medical device preemption cases are analyzed under express preemption concepts due to $\S 360 \mathrm{k}$. Drug cases are analyzed under implied preemption concepts. ${ }^{157}$ The Court in Wyeth explicitly noted that a drug equivalent preemption provision to the medical device preemption set forth in $\S 360 \mathrm{k}(\mathrm{a})$ was non-existent. ${ }^{158}$ In citing Riegel, the

\footnotetext{
150. Id.

151. Id. at 323 .

152. Id.

153. Id. at 323-24.The Court in Riegel did not discuss the impact of the 1990 SMDA on $510(\mathrm{k})$ preemption.

154. Wyeth v. Levine, 555 U.S. 555, 558 (2009).

155. Id.

156. Id. at 573-81.

157. The specific differences between express and implied preemption have been addressed by courts and commentators. Given that we focus on $\S 360 \mathrm{k}$ and express preemption, these differences are not relevant to our analysis.

158. Section $360 \mathrm{k}$ preempts a state from supplying additional or contrary requirements for medical devices. Contra Wyeth, 555 U.S. at 583 (Thomas, J., concurring) (stating that it was possible for Wyeth to label Phenergan in compliance with the FDA regulations and also provide additional warnings re-
} 
Court concluded that in an implied preemption case, unless there was a "direct and positive conflict" between state law and the FDCA, state common law suits were not preempted. ${ }^{159}$ In Wyeth, the Court determined it was possible for the drug manufacturer to comply with both state and federal law. ${ }^{160}$ While the FDA has authority to reject the drug label change, the drug manufacturer, not the FDA, is responsible for maintaining its labeling. It is important to distinguish drug and device cases. Wyeth concerned a drug, not a device; medical device preemption is analyzed under express preemption concepts and $\S 360 \mathrm{k}$. Conversely, drug preemption is analyzed under implied preemption doctrine, and devices and drugs have unique regulatory structures.

In PLIVA, Inc. $v$. Mensing, another federal preemption case, two consumers brought a products liability action under state tort law against a generic drug manufacturer. ${ }^{161}$ They alleged that the manufacturer failed to provide adequate warnings on their generic drug labels. ${ }^{162}$ The key issue in Mensing was whether a generic drug manufacturer could change their drug's labeling in accordance with state law requirements after initial FDA approval. ${ }^{163}$ Under FDA regulation, a generic drug manufacturer must contact the FDA if they believe new safety information should be added to their drug's label.164 The FDA

quired by the state). This is unique to drugs as they have their own regulatory scheme.

159. Wyeth, 555 U.S. at 567 (quoting Riegel v. Medtronic, Inc., 552 U.S. 312, 342 (2008)); see also Matthew S. Reid, Comment, Vermont Supreme Court Rules That Food and Drug Administration Regulations Do Not Preempt State Failure-to-Warn Claims-Levine v. Wyeth, 944 A.2d 179 (Vt. 2006)., 4 J. HEALTH \& BIOMED. L. 413, 420 (2008) (noting that the FDA regulation of drug labeling only sets a floor; states' requirements imposing greater labeling requirements for drugs are enforceable); see generally 21 C.F.R § 314.70 (2011) (codifying minimum requirements for drug labels).

160. Wyeth, 555 U.S. at 568. In particular, the court focused on the "changes being effected" or "CBE" provisions found in 21 C.F.R. $§ 314.70(\mathrm{c})(6)$. Id.

161. PLIVA, Inc. v. Mensing, 131 S.Ct. 2567, 2572 (2011).

162. Id. State tort law-Minnesota and Louisiana in this case-requires "a drug manufacturer that is or should be aware of its product's danger to label that product in a way that renders it reasonably safe." Id. at 2573.

163. Id. at 2574. Just to note, under FDA regulations, generic drugs must have identical labels to their name brand counterparts. See Abbreviated New Drug Application Regulations, 57 Fed. Reg. 17950-01 (Apr. 28, 1992) (codified at 21 C.F.R. pts. $2,5,10,310,314,320, \& 433)$

164. Abbreviated New Drug Application Regulations, 57 Fed. Reg. 1795001 (Apr. 28, 1992) (codified at 21 C.F.R. pts. 2, 5, 10, 310, 314, 320, \& 433). 
then determines if the drug labeling should be strengthened.165 Due to these FDA requirements, the Court in Mensing found conflict preemption; it was impossible for the generic drug manufacturer to comply with state law and strengthen their warning, while remaining in compliance with the federal law. ${ }^{166}$

Mensing raised an additional question as to whether conflict preemption should consider situations where the FDA had the authority to act but did not act. For example, in Mensing the appellees argued that successfully proving preemption requires the generic drug manufacturer to show that the FDA would not have allowed compliance with both state and federal law. ${ }^{167}$ In this case, it was at least possible that the FDA would have allowed the generic drug manufacturer to strengthen their drug label had they asked the FDA. ${ }^{168}$ The Court ruled, however, that the Supremacy Clause does not permit this approach to preemption. "The Supremacy Clause, on its face, makes federal law 'the supreme Law of the Land' even absent an express statement by Congress." 169 The Court ultimately held that federal law preempted the state law that required a change in the generic drug company's label, despite the fact that the FDA had the authority to approve a stronger warning label. 170

\section{ANALYSIS}

\section{A. SUMMARY OF PREEMPTION ELEMENTS UNDER § 360K AND RELEVANT SUPREME COURT PRECEDENT}

If one consolidates the medical device related preemption statutory elements under $\S 360 \mathrm{k}$, the FDA's implementing regulations under 21 C.F.R. $§ 808$, and relevant Supreme Court jurisprudence, one can derive a core set of requirements or el-

165. Id.

166. Mensing, 131 S.Ct. at 2577-79. "The question for 'impossibility' is whether the private party could independently do under federal law what state law requires of it." Id. at 2579. In Mensing, the generic drug manufacturer could not strengthen its label in accordance with state law and still be in compliance with federal law. $I d$.

167. Id. at $2578-79$

168. Id. at 2587 .

169. Id. at 2579 .

170. Id. at 2582 . 
ements that must be satisfied before the courts will accept a preemption defense. ${ }^{171}$

\section{Required Preemption Elements}

First, the FDA must have the authority to impose safety and effectiveness related requirements on the device in question. ${ }^{172}$ Section $360 \mathrm{k}$ preempts a state requirement that "relates to the safety or effectiveness of the device or to any other matter included in a requirement applicable to the device under this chapter." 173 The core finding in Lohr was that the FDA, at the time it cleared Medtronic's 4011 lead, did not impose, or have the authority to impose, safety and effectiveness requirements on the product. The Lohr Court found that the FDA had not made a safety or effectiveness determination when it cleared the pacemaker lead at issue. Conversely, in Riegel, the Supreme Court held that the PMA system in place when the catheter at issue in that case was approved did make a safety and effectiveness determination. ${ }^{174}$ Thus, one key element for a preemption defense is to establish that the regulatory system through which the product was permitted to be marketed makes, or has the authority to make, a safety and effectiveness determination. ${ }^{175}$

171. It is not our intent to debate or analyze the correctness of the Supreme Court's interpretation of $\S 360 \mathrm{k}$ in Lohr or Riegel. We recognize that some (including some dissenting judges) question various aspects of Supreme Court preemption jurisdiction. For example, there have been debates whether a state product liability verdict is a "requirement" within the meaning of the "parallel claim" language in Riegel; whether there should be preemption for IDE products; or what is the relationship of preemption cases such as Riegel to Buckman v. Plaintiffs Legal Committee, and Buckman's "fraud on the FDA" language. See Buckman v. Plaintiffs Legal Committee, 531 U.S. 341 (2001).

172. The issue of whether the FDA has the authority to impose requirements is different from the question whether a state court product liability verdict is a "requirement" for preemption purposes. In several cases, including Lohr and Riegel, the Supreme Court determined that state court product liability verdicts can be "requirements" for preemption purposes.

173. Food, Drug and Cosmetic Act, 21 U.S.C. $\$ 360 \mathrm{k}(\mathrm{a})(2)$ (2006).

174. See Section II.E. Preemption applies if the agency has the statutory and regulatory authority necessary to satisfy the requirements of $\S 360 \mathrm{k}$. Preemption applies even if the agency makes the wrong safety or effectiveness determination or otherwise inadequately implements the statutory authority given it. Preemption is a question of agency authority, not agency implementation or agency decision-making.

175. Because product liability cases almost universally involve questions of safety, the role of the regulatory system in making effectiveness determinations is rarely an issue. 
Second, the agency must have the authority to impose the regulatory requirements that are specific to the device. For example, in Lohr, the defendant argued that the "general controls" 176 applicable to the pacemaker lead were safety and effectiveness determinations. The Court rejected this argument because, in the Court's opinion, general controls applied to all devices without regard for the particular nature or features of the actual device. ${ }^{177}$ Conversely, the Supreme Court held that the PMA requirements at issue in Riegel were specific to the device because each PMA individually analyzes a device and so satisfied this element of preemption. In reaching this conclusion, the Court looked at the statutory provisions ${ }^{178}$ requiring a safety and effectiveness determination by the FDA for any PMA submission and the content of the application and approval documents. ${ }^{179}$ The Court was also heavily influenced by the fact that the company could not make product changes without prior FDA review and approval. ${ }^{180}$

Cases such as Wyeth and Mensing turned on whether the company could modify the product in question or the product labeling without prior FDA approval. The idea is that the inability of the company to unilaterally make product changes demonstrates both that the FDA is fully occupying the field (a necessary part of implied or field preemption) and demonstrates that the proposed change in the product is a new requirement that is different from or in addition to FDA requirements - a key element of preemption under $\S 360 \mathrm{k}$. The statute (§360k) itself does not explicitly create this "specificity" element. The statute simply talks about safety and effectiveness.

The Court in Lohr used the FDA's implementing regulations as a key basis for the specificity requirement. Chapter 21

176. General controls include manufacturing systems (so-called good manufacturing practices (GMPs)), quality system regulations (QSRs), and facility and device registration. The role of general controls in product safety is set forth in 21 U.S.C. $§ 360$ c(a)(1)(A)(i) (2006).

177. Medtronic, Inc. v. Lohr, 518 U.S. 470, 476-77 (1996).

178. 21 U.S.C. $\S 360$ e sets out detailed requirements for the content of a PMA submission and the criteria by which the agency approves or rejects the application.

179. Riegel v. Medtronic, Inc., 552 U.S. 312, 313 (2008).

180. Contra Wyeth v. Levine, 129 S. Ct. 1187, 1196 (2009) (discussing how a drug company was able to make changes to the drug labeling without FDA approval through the $\mathrm{CBE}$ regulation). The $\mathrm{CBE}$ provision is not available to device manufacturers under the $510(\mathrm{k})$ provisions. 
C.F.R. $\S 808.1(\mathrm{~d})$ states:

State or local requirements are preempted only when the Food and Drug Administration has established specific counterpart regulations or there are other specific requirements applicable to a particular device under the act, thereby making any existing divergent State or local requirements applicable to the device different from, or in addition to, the specific Food and Drug Administration requirements.

In addition, in its implementing regulations, the FDA explicitly stated that state requirements that are of general applicability are not preempted by $\S 360 \mathrm{k} .{ }^{181}$ The purpose of the "specificity" requirement appears to be to permit local nondevice requirements to be effective. Examples of requirements of general applicability include local zoning requirements, electrical codes, and permitting requirements.

These regulatory and statutory provisions, together with the Court's overall view on preemption, led to the Court asserting that in order for there to be preemption, the FDA must impose, or have the power to impose, device specific requirements relating to safety and effectiveness.

Many medical device preemption cases involve allegations that the product should have warnings or safety features not required by the FDA. Preemption exists if the FDA had the authority to impose such obligations but did not do so. These are covered by the "in addition to" clause of $\S 360 \mathrm{k}$. The fact that the FDA did not impose a requirement is irrelevant if the FDA had the authority to impose that requirement.

Third, only state requirements that are "different from, or in addition to, any requirement applicable under this chapter to the device" are preempted.182 Product liability claims that are "parallel" to FDA requirements are not preempted. ${ }^{183}$

2. Understanding the Meaning of "Different from" and "in Addition to"

Section $360 \mathrm{k}(\mathrm{a})(1)$ requires preemption (assuming all other conditions for preemption have been met) in two situations.

181. 21 C.F.R. § 808.1(d)(1), (3), (6) (2011).

182. 21 U.S.C. $\S 360 \mathrm{k}(\mathrm{a})(1)$ (2006).

183. Riegel, 552 U.S. at 330. The definition of what is "parallel" and the intersection between the "parallel claim" language in Riegel and the prohibition of private causes of action under Buckman is outside of the scope of this

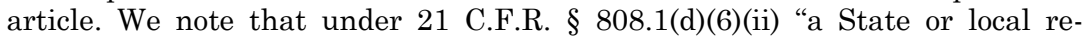
quirement prohibiting the manufacture of adulterated or misbranded devices" is not preempted-presumably as long as it is a "parallel" claim under Riegel. 
First, there is preemption in situations in which the FDA has affirmatively created device specific requirements that are "different from" the plaintiff's claim or the jury's decision. While this situation can generally be analyzed as express preemption, it also can be viewed as conflict preemption. If the FDA requires a two-inch wire and the plaintiff is asserting that the wire should be one-inch, 184 one can find either express preemption under $\S 360 \mathrm{k}$ (the "different from" prong of 21 U.S.C. $360 \mathrm{k}(\mathrm{a})(1))$ or conflict preemption because the defendant literally could not comply with both requirements at the same time. These "different from" or conflict cases are not common.

Most preemption cases since Lohr have involved situations in which the plaintiff is asserting that the defendant should have done something more than what the FDA required under the PMA or cleared under the 510(k). ${ }^{185}$ This can include, for example, assertions that additional warnings should have been given, or some part of the device could have been designed in a more robust fashion. These cases are not conflict preemption cases because, for example, the plaintiff argues the defendant could physically have added the warning without contradicting any actual FDA mandated warning. Rather, these cases must be analyzed under the "in addition to" prong of $\S 360 \mathrm{k}(\mathrm{a})(1)$. These "in addition to" cases involve situations in which the FDA had the statutory authority to compel the defendant to do whatever the plaintiff asserts should have been done, but the FDA did not compel the additional warning or different design. For example, in the PMA context, the courts recognize that the FDA could have compelled additional warnings as part of the PMA approval process. ${ }^{186}$ In this PMA context, the state requirement is "in addition to" whatever FDA actually required and thus is preempted.

The key is that the "in addition to" prong of $\S 360 \mathrm{k}$ covers all situations in which the FDA has the power to act but has

184. This is Justice Breyer's famous example in his concurrence in part and concurrence in the result in Lohr. Medtronic, Inc. v. Lohr, 518 U.S. 470, 504 (1996).

185. See, e.g., Martin v. Telectronics Pacing Systems, 105 F.3d 1090 (6th Cir. 1997); Webster v. Pacesetter, Inc., 171 F. Supp. 2 d 1 (D.D.C. 2001).

186. Many products are modifications of PMA products and so go through a supplemental PMA process. See 21 C.F.R. § 814.39 (2011). For our purposes, there is no meaningful difference between an original PMA and a supplemental PMA. Courts have not found any difference for preemption purposes. See, e.g., Blunt v. Medtronic, Inc., 760 N.W.2d 396, 405-08 (Wis. 2009). 
not done so for whatever reason. Section 360k clearly creates minimum standards. If the FDA requires a warning on the label and the defendant fails to include that warning, the plaintiff may well have a relatively easy "parallel claim" case (assuming proximate causation and all of the other traditional requirements of a product liability case). However, the FDA does much more than simply create minimum standards. The FDA also creates maximum standards. A product approval is a balancing act. Different designs and different warnings create different advantages and disadvantages. Adding a warning can, for example, actually cause harm as patients and physicians change prescribing habits. ${ }^{187}$ A classic example of this occurred when new teen suicide warnings were added to serotoninspecific reuptake inhibitors (SSRIs) - a type of antidepressant. Actual product use decreased and the number of suicides increased. 188

The FDA has been authorized by Congress to make these balances. Permitting state product liability cases to impose additional requirements undermines this authority. Thus, the "in addition to" prong of $\S 360 \mathrm{k}$ preempts a state court from imposing other design, labeling, or manufacturing requirements. Preemption covers the ability to impose requirements, not just the existence of a requirement.

\section{If Modifications Require FDA Approval, Preemption Exists}

A key question in a medical device product liability case is whether a manufacturer is permitted to make some design change or change in warnings for a $510(\mathrm{k})$ product without prior FDA concurrence.

In determining whether the FDA has the right to impose both the minimum and maximum requirements, courts often look at whether the change being proposed by the plaintiff could be implemented without FDA approval. If FDA approval is needed, then courts generally hold that there is preemption. This approach is best demonstrated by Wyeth $v$. Levine. ${ }^{189}$ In this drug product liability case, the Supreme Court was faced with an implied preemption argument.190 The plaintiff argued

187. See generally Ralph F. Hall, The Risk of Risk Reduction: Can Postmarket Surveillance Pose More Risk than Benefit?, 62 FOOD \& DRUG L.J. 473, 485-87 (2007) (describing the reduction of SSRI use and FDA's response).

188. Id. at 486 .

189. Wyeth v. Levine, 129 S. Ct. 1187, 1198 (2009).

190. There is no statutory equivalent to $\S 360 \mathrm{k}$ in the drug provisions of the 
[Vol. 13:2

that Wyeth should have added new or additional warnings to it label for the drug in question. The defendant countered by arguing that its label was FDA approved. The Supreme Court sided with the plaintiff and found that Wyeth could have unilaterally added the warning advocated by the plaintiff using the "changes being effected" (CBE) process set forth in the drug regulations. 191

The Supreme Court continued to follow this approach when it found preemption in a generic drug case because the generic drug manufacturing was not covered by the CBE provisions applicable to the name brand. As a result, the generic drug company could not make any change without prior FDA approval, and the plaintiff's failure to warn claim was preempted. ${ }^{192}$ In essence, a requirement is specific to a device (or drug) if the manufacturer could not change or modify the product to address that requirement without prior FDA approval.

This question is directly answered for $510(\mathrm{k})$ products by existing FDA regulations and guidance, which establish that changes to $510(\mathrm{k})$ products intended to address safety or effectiveness issues or which could substantially affect safety or effectiveness cannot be implemented without prior FDA review and clearance. Chapter 21 C.F.R. § 807.81(a) states:

[E] ach person ... must submit a premarket notification submission to the Food and Drug Administration at least 90 days before he proposes to begin the introduction or delivery for introduction into interstate commerce for commercial distribution of a device intended for human use which meets any of the following criteria:

(3) The device is one that the person currently has in commercial distribution or is reintroducing into commercial distribution, but that is about to be significantly changed or modified in design, components, method of manufacture, or intended use. The following constitute significant changes or modifications that require a premarket notification:

(i) A change or modification in the device that could significantly affect the safety or effectiveness of the device, e.g., a significant change or modification in design, material, chemical composition, energy source, or manufacturing process. ${ }^{193}$

FDCA. Courts, including Levine have used implied preemption doctrine as the basis for preemption arguments.

191. 21 C.F.R. $\S 314.70(c)(6)$ (2008).

192. PLIVA, Inc. v. Mensing, 131 S.Ct. 2567, 2580-81 (2011).

193. 21 C.F.R. $§ 807.81$ (a) (2011) (emphasis added). 
As stated in the regulation and accompanying guidance, a company must submit a new $510(\mathrm{k})$ whenever it wishes to make a change to an already cleared device and that change "could significantly affect the safety or effectiveness of the device." 194 This places products under the $510(\mathrm{k})$ system in the same category as cases such as Mensing in which the Supreme Court found preemption in large part because the company could not make a product change without prior FDA approval. Likewise, this regulatory structure differentiates the $510(\mathrm{k})$ system from the new drug world of Levine in which the company could make a change prior to FDA approval. ${ }^{195}$

The same general requirements apply to PMA devices. ${ }^{196} \mathrm{~A}$ company cannot distribute a PMA product with a change that could affect safety or effectiveness. ${ }^{197}$ This fact supported the finding of preemption in Riegel. In that case the company couldn't make the change required by the plaintiff's theory

194. Current guidance explaining and implementing these requirements can be found at: OFFICE OF DEviCE EVALUATION, DECIDING WHEN TO SUBMIT A 510(K) FOR A CHANGE TO AN EXISTING DEVICE 1 (1997), available at http://www.fda.gov/downloads/MedicalDevices/DeviceRegulationandGuidance/ GuidanceDocuments/ucm080243.pdf. Note that the FDA has recently issued a draft update to this guidance. See, e.g., OFFICE OF DEvicE Evaluation, GUIDANCE FOR INDUSTRY AND FDA STAFF-510(K) DEVICE MoDifications: DECIDING When to SubMit A 510(K) FOR A CHANGe TO AN EXISTING DEVICE (2011), available at http://www.fda.gov/downloads/MedicalDevices/DeviceReg ulationandGuidance/ GuidanceDocuments/UCM265349.pdf. This guidance is still in draft form. The differences between the 1997 guidance and the new draft guidance are not relevant to the question of whether the FDA has the authority to require a new $510(\mathrm{k})$ if a company is making a change that could significantly affect safety.

195. If a company does make a change to a $510(\mathrm{k})$ device and markets that product prior to FDA approval, the agency can always exercise its enforcement discretion and not bring an administrative, civil, or criminal action. It may well be that the FDA might, in certain circumstances decide not to bring an enforcement action. That enforcement discretion decision does not, however, magically make an illegal act legal.

196. The $510(\mathrm{k})$ system requires a submission if a change could significantly affect safety. The PMA system requires a new submission for a change that could affect safety. While this linguistic difference is important to regulatory professionals, it is hard to imagine a product liability lawsuit in which the plaintiff argues that the defendant should have made a change, but that the change could not significantly affect safety. The causation basis of the plaintiff's case is that his or her injuries were, in fact, caused by the failure to make the change advocated by the plaintiff.

197. 21 C.F.R. $\S 814.39$ (2008). Note that, unlike the $510(\mathrm{k})$ system, the PMA system can, in unusual circumstances, permit certain limited types of changes to be made while the FDA is reviewing the supplemental PMA. See $i d$. 
without prior FDA approval.198 The parallel modification requirements for PMA and 510(k) devices further reinforces the conclusion that modern $510(\mathrm{k})$ products are under the Riegel rule, not the Lohr approach.

The post Lohr regulatory system is consistent with wellestablished Supreme Court preemption law. The manufacturer of a $510(\mathrm{k})$ product cannot make a change which could significantly affect safety without prior FDA clearance of a new $510(\mathrm{k})$ submission covering that change. Thus, preemption un$\operatorname{der} \S 360 \mathrm{k}$ should apply.

\section{B. PREEMPTION UNDER $§ 360 \mathrm{~K}-\mathrm{AND}$ Why LOHR DOES NoT APPLY TO CURRENT 510(K) PRODUCTS}

In Lohr, the Court conducted a statutory analysis of the $510(\mathrm{k})$ system as it existed in 1982 and concluded that the FDCA did not preempt the plaintiff's product liability claims. ${ }^{199}$ However, the precedential impact of Lohr for 510(k) products cleared under the current system is highly questionable. This view is not based on an argument that Lohr itself was incorrectly decided. Rather, the medical device statutes have changed dramatically in the thirty years since 1982, and the courts cannot and should not ignore these changes. As such, the Supreme Court's analysis of the 1982 510(k) system for preemption purposes is not outcome determinative for whether there is preemption under the $2012510(\mathrm{k})$ system.

In analyzing $510(\mathrm{k})$ preemption, it is important not to be misled by the date of the decision in Lohr. The Supreme Court's decision was handed down in 1996. That is not the relevant date. The Court (quite correctly) analyzed the statutory system as it existed at the time the product in question was cleared by the FDA — that was in 1982. To understand the holding and limitations of Lohr one must look at the $510(\mathrm{k})$ system as it existed at that time. ${ }^{200}$

198. Riegel v. Medtronic, Inc., 552 U.S. 312, 312-13 (2008).

199. Medtronic, Inc. v. Lohr, 518 U.S. 470, 503 (1996).

200. Interestingly - and in full support of this view-the Court in Lohr did not analyze the SMDA and its role in preemption. The Court only mentions the SMDA in two places: in footnote 3 of the case, which pointed out how the SMDA and subsequent FDA actions could change the regulatory classification of pacemakers, and in footnote 4, which also pointed out how the SMDA had changed the device regulatory system. Surely the Supreme Court would have reviewed the regulatory system post-SMDA if that had been relevant to the 
A similar statutory interpretation of today's FDCA, in conjunction with the FDA's own view of the 510(k) system and actual $510(\mathrm{k})$ clearance records, reveals that the $510(\mathrm{k})$ process does assess safety and effectiveness and that there are specific requirements for products. Therefore, the $510(\mathrm{k})$ system should preempt product liability claims against devices cleared under the current $510(\mathrm{k})$ system. ${ }^{201}$

\section{ImPACT OF the SAFE MedicAl Device ACT of 1990}

Medical technology and the clinical application of medical devices experienced a rapid expansion between the Medical Device Amendments in 1976 and the Safe Medical Devices Act of 1990 (SMDA). The introduction of new technologies and medical devices required Congress and the FDA to modify the then existing regulatory system. In fact, the explicit purpose of the SMDA was to substantially enhance the oversight of medical devices including making major changes to the $510(\mathrm{k})$ process.

Consistent with the Court's analysis in Lohr, a statutory interpretation of $\S \S 360 \mathrm{k}$ and 513(i) ${ }^{202}$ should start with a fair understanding of congressional purpose of the current regulatory scheme. The lead at issue in Lohr predated the SMDA. If a similar situation arose today, the Court would analyze "substantial equivalence" as defined in the SMDA and subsequent congressional and regulatory enactments.

In this instance, the purpose of Congress in enacting the SMDA is clear-the Act was to further a policy promoting the safety and effectiveness of medical devices by providing a more stringent or robust regulatory frame to effectuate that purpose. ${ }^{203}$ After the SMDA, the FDA had substantially more ro-

case. The Court, quite correctly, looked only at the $1982510(\mathrm{k})$ system. Lohr, thus, does not address the 510(k) system for products cleared after 1990 .

201. As we discuss at length, at the relevant time for the Lohr analysis, the $510(\mathrm{k})$ clearance process was different from the current process. We do not argue that Lohr was incorrectly decided, but rather, in light of the 510(k) clearance process conducted today, Lohr does not control preemption cases involving products cleared today and a new standard should be applied in $510(\mathrm{k})$ product liability suits.

202. Food, Drug \& Cosmetic Act § 513(i), 21 U.S.C. § 360c(i)(3) (2006). Section 513(i) now contains the provisions referring to substantial equivalence.

203. In 1997, the passage of the FDAMA furthered Congress's purpose of increasing safety and effectiveness of market distributed products. See Linda A. Suydam \& Milan J. Kubic, FDA's Implementation of FDAMA: An Interim Balance Sheet, 56 FoOD \& DRUG L.J. 131, 131 (2001) (noting the "exceptional addition" FDAMA provided the FDA with statutory authority in addition to "reaffirming the agency's vital importance for the protection of public health"). 
bust authority to ensure the safety and effectiveness of medical devices in furtherance of congressional policy.

The $1982510(\mathrm{k})$ system (based on the 1976 MDA) relied upon performance standards and a physical comparison of products as the means to provide the necessary reasonable assurance of safety and effectiveness. Instead of relying on performance standards (an approach that turned out to be unwieldy), the SMDA instead utilized the concept of "special controls." 204 Special controls can include, among other requirements, clinical data, bench testing, satisfaction of consensus standards, use of specific materials, and post-market surveillance. ${ }^{205}$

The SMDA also added, for the first time, a statutory definition of substantial equivalence. ${ }^{206}$ The Supreme Court in Lohr did not face or decide the question of whether the new statutory definition of substantial equivalence, together with the added control mechanism provided by special controls, demonstrates that the post-1990 510(k) system does address safety and effectiveness. The bottom line is that if the Medtronic lead at issue in Lohr was cleared through the 510(k) process of today's statutory framework - the more robust process created by the SMDA - there would be a much greater assessment of the safety and effectiveness of the lead. Under the current FDCA, the FDA has the statutory authority to impose special controls, require data submission, and make a clear determination of the safety and effectiveness of the lead prior to its clearance and market release.

\section{510(K) ASSESSMENT OF SAFETY AND EFFECTIVENESS: OPINIONS OF THE FDA}

In Lohr, the Court concluded that the 1982 version of "the $510(\mathrm{k})$ process was [not] intended to do anything other than maintain the status quo, which included the possibility that a device's manufacturer would have to defend itself against statelaw negligent design claims." 207 At the time of Lohr, the FDA may have even agreed that there was no assessment for safety and effectiveness of a $510(\mathrm{k})$ device's design. In contrast, the

\footnotetext{
204. 21 U.S.C. $\S 360 c(a)(1)(B)(2006)$.

205. See 21 C.F.R. $\S 860.3(\mathrm{c})(2)$ (2011).

206. 21 U.S.C. $\$ 360 \mathrm{c}(\mathrm{i})$.

207. Medtronic, Inc. v. Lohr, 518 U.S. 470, 471 (1996).
} 
FDA today asserts that after several "statutory and regulatory modifications over time, [the $510(\mathrm{k})$ system] has become a multifaceted premarket review process that ... provide[s] reasonable assurance of safety and effectiveness [and] facilitate[s] innovation in the medical device industry." 208 The $510(\mathrm{k})$ process is now the principal route used for medical devices to reach market.209

The FDA's assessment of the program it runs is critical. The FDA is neutral and has the greatest expertise. The agency's mission is to protect public health and provide a reasonable assurance of safety and effectiveness. An effective 510(k) system is obviously critical to that goal.

\section{The FDA Asserts That It Is Making Safety and Effectiveness} Determinations for 510(k) Devices

The FDA has very recently reaffirmed that today's $510(\mathrm{k})$ system does assess safety and effectiveness. In December 2011, the Center for Devices and Radiological Health $(\mathrm{CDRH})$ issued a draft guidance regarding how it assesses "substantial equivalence" under the $510(\mathrm{k})$ process. ${ }^{210}$ This draft guidance explicitly states that the $510(\mathrm{k})$ program does assess safety and effectiveness:

Because devices are classified according to the level of regulatory control necessary to provide a reasonable assurance of safety and effectiveness, classification of a new device through the $510(\mathrm{k})$ process requires FDA to determine the issues of safety and effectiveness presented by the new device, and the regulatory controls necessary to address those issues. 211

The FDA continues and states that "the principles of safety

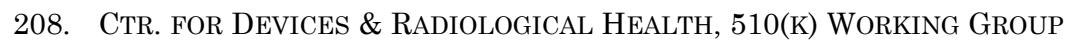
PRELIMINARY REPORT AND RECOMMENDATIONS, CDRH PRELIMINARY INTERNAL EVALUATIONS 34 (Aug. 2010), available at http://www.fda.gov/downloads/AboutFDA/CentersOffices/CDRH/CDRHReports /UCM220784.pdf.

209. Heather S. Rosecrans, Dir., 510(k) Staff, When to Submit (or Not) a 510K, That Is the Question!. Presentation at the AMDA/FDA-OVID Workshop (Apr. 20, 2010), http://www.amdm.org/presentations.html (follow "OVID Submissions Workshop" hyperlink, download and open the .zip file, then open the "Rosecrans.pdf").

210. DRAFT GUIDANCE, supra note 53, at 1, 5-8. Note that guidance documents, including this Draft Guidance, do not and cannot create new policy. Id. at 1 ; see also 21 C.F.R. $\S 10.115$ (2011). Rather, guidance documents further explain or describe existing policy and requirements. As such, the Draft Guidance does not reflect any substantive changes in how the $510(\mathrm{k})$ system assesses safety and effectiveness. Id.

211. DRAFT GUIDANCE, supra note 53, at 3 (footnotes omitted). 
and effectiveness underlie the substantial equivalence determination in every $510(\mathrm{k})$ review." 212

What has confused some about the $510(\mathrm{k})$ system, in addition to the fundamental changes made to the system over thirty-five years, is that the $510(\mathrm{k})$ system uses a different means to assess safety and effectiveness than does the PMA system. Each PMA is a separate review and does not require comparison to another device. The 510(k) system instead compares the device under review to another, already cleared device, for which a "reasonable assurance of[] safety and effectiveness" has already been demonstrated and uses special controls to impose safety and effectiveness requirements on product types. ${ }^{213}$ The 2011 Draft Guidance explains this as follows:

Although the $510(\mathrm{k})$ process involves a comparison of a new device to a predicate device rather than an independent demonstration of the new device's safety and effectiveness, as is required for approval of a PMA, in both cases FDA's review decision reflects a determination of the level of control necessary to provide a "reasonable assurance of safety and effectiveness." The evidentiary standard, however, is different. In the $510(\mathrm{k})$ context, FDA generally relies, in part, on FDA's prior determination that a reasonable assurance of safety and effectiveness exists for the predicate device. ${ }^{214}$

What could be clearer? The FDA specifically states that the current $510(\mathrm{k})$ system makes a safety and effectiveness determination.

Section 360k does not limit or specify the way in which the FDA assesses device safety and effectiveness. Rather, it simply requires that the FDA do so in order for there to be preemption. Earlier guidance also confirms that, at least post-SMDA, the FDA does make a safety and effectiveness determination as part of the clearance process. A key guidance describing the $510(\mathrm{k})$ system states: "Section 513(i) of the Act states that the FDA may issue an order of substantial equivalence only upon making a determination that the device to be introduced into commercial distribution is as safe and effective as a legally marketed device."215

212. Id. at 6

213. 21 C.F.R. $\S 860.7$ (2011).

214. DRAFT GUIDANCE, supra note 53, at 7 (emphasis added) (footnote admitted).

215. CtR. For Devices \& Radiological Health, The NeW 510(K) PARADIGM-ALTERNATIVE APPROACHES TO DEMONSTRATING SUBSTANTIAL Equivalence in PREMARKet Notifications -Final Guidance 1 (1998), 
Further evidence from the FDA's own documents also demonstrates that the FDA is making a safety and effectiveness finding for $510(\mathrm{k})$ devices. First, in September of 2007, the $\mathrm{CDRH}$, the department in charge of overseeing medical device regulation, released to the public a guidance document providing direction to reviewers and industry alike on the use of national consensus standards in medical device evaluation. In this guidance document, $\mathrm{CDRH}$ explicitly states that it "believes that conformance with recognized consensus standards [a means of showing substantial equivalence under the $510(\mathrm{k})$ system] can support a reasonable assurance of safety and/or effectiveness for many applicable aspects of medical devices."216

Again, in December 2011, the CDRH published a draft guidance document detailing the current "statutory framework" of the $510(\mathrm{k})$ clearance process. ${ }^{217}$ Issued as recommendations for the future of $510(\mathrm{k})$, this guidance document makes clear that the FDA is not only currently conducting a safety and effectiveness determination for $510(\mathrm{k})$ devices, but that safety and effectiveness are at the crux of $510(\mathrm{k})$ clearance decisions. For instance, when describing the $510(\mathrm{k})$ review standard, the CDRH states that "[s]afety and effectiveness factor into both parts of [the $510(\mathrm{k})$ ] review standard." 218 The guidance document goes on to conclude that "in both cases [PMA and 510(k) review] FDA's review decision reflects a determination of the level of control necessary to provide a 'reasonable assurance of safety and effectiveness."'219

In addition to specific statements found in guidance documents, the requirements for the content of a $510(\mathrm{k})$ submission establish that a safety and effectiveness determination is taking place. The CDRH's regulations detail what the sponsor of a

available at http://www.fda.gov/MedicalDevices/DeviceRegulationandGuidance /GuidanceDocuments/ucm080187.htm.

216. CTR. FOR DEVICES \& RADIOLOGICAL HEALTH, GUIDANCE FOR INDUSTRY AND FDA STAFF-RECOGNITION AND USE OF CONSENSUS STANDARDS 5 (2007), available at http://www.fda.gov/downloads/MedicalDevices/DeviceRegulationandGuidance/ GuidanceDocuments/ucm077295.pdf [hereinafter CONSENSUS STANDARDS].

217. DRAFT GUIDANCE, supra note 53, at 3; see CONSENSUS STANDARDS, supra note 216 , at $4-5$ (reinforcing that the $510(\mathrm{k})$ provision is in place to promote the FDA's public health mission by ensuring devices are safe and effective when marketed. The CDRH also recognizes that past implementations of the $510(\mathrm{k})$ may have failed to adequately achieve this goal).

218. DRAFT GUIDANCE, supra note 53, at 7.

219. Id. 
$510(\mathrm{k})$ must submit in order to obtain clearance. Among other requirements, the sponsor is required to submit to $\mathrm{CDRH}$ a summary of safety and effectiveness or a $510(\mathrm{k})$ statement. ${ }^{220}$ Chapter 21 C.F.R. $\S 807.92$ (a) states that for a finding of substantial equivalence, "[a] 510(k) summary shall be [submitted] in sufficient detail to provide an understanding of the basis for a determination of substantial equivalence." 221 More specifically, Congress requires that a $510(\mathrm{k})$ submission "shall provide an adequate summary of any information respecting safety and effectiveness or state that such information will be made available upon request by any person." 222 This $510(\mathrm{k})$ statement or summary of safety and effectiveness is also made available to the public within thirty days of a substantial equivalence decision for the $510(\mathrm{k})$. ${ }^{223}$ Furthermore, the FDA requires the $510(\mathrm{k})$ submitter-if they choose to submit a $510(\mathrm{k})$ summary in lieu of a $510(\mathrm{k})$ statement to submit "[t]he conclusions drawn from the nonclinical and clinical tests that demonstrate that the device is as safe, as effective, and performs as well as or better than the legally marketed device identified[as a predicate device]." 224 The requisite scientific evidence includes performance data-both clinical and nonclinical tests-that were used by the manufacturer. ${ }^{225}$ Remember that this type of information historically was only required for PMA devices and was not required for Medtronic's 4011 lead to prove substantial equivalence. Today, the FDA may also request additional information prior to clearing the device for market if the information has relevance to the FDA's review; namely, the FDA reviews "all available safety and effectiveness information" available for the medical device. ${ }^{226}$

Thus the requisite basis and additional scientific information submitted with every $510(\mathrm{k})$ submission substantiates the FDA's safety and effectiveness determination because the basis of clearance requires evidence demonstrating that the de-

\footnotetext{
220. 21 C.F.R. $§ 807.92$ (2011).

221. Id. (emphasis added).

222. 21 U.S.C. $§ 360$ c(i)(3)(A) (2006).

223. 21 U.S.C. $\S 360 \mathrm{c}(\mathrm{i})(3)(\mathrm{B})$.

224. 21 C.F.R. $\S 807.92(b)(3)$.

225. See id. (requiring only data that show substantial equivalence). This contrasts the PMA process where such clinical studies are required to show safety and effectiveness.
}

226. CTR. FOR DEVICES \& RADiOlOGiCAL HEALTH, supra note 208, at 73. 
vice operates similarly to its predicate, and that the device is safe and effective for its intended purpose. The FDA's implementing regulations reinforce these requirements.

The Office of Device Evaluation and the Office of In Vitro Diagnostics also explicitly states new devices are "not substantially equivalent" if they do not demonstrate they are at least as safe and effective, if not more so, as their predicate. ${ }^{227}$ It logically follows that to determine whether a device is "at least as safe and effective" as the predicate device, one must determine how safe and effective the new device is. When is the FDA determines that a $510(\mathrm{k})$ device is "at least as safe and effective" as its predicate, that determination is a conclusion that the device is sufficiently safe and effective for clearance. ${ }^{228}$ Stated differently, a clearance is granted when the FDA believes the $510(\mathrm{k})$ sponsor has provided information to provide reasonable assurance of the device's safety and effectiveness in order to demonstrate substantial equivalence. Consistent with this conclusion, $\S 360 \mathrm{k}$ should apply to $510(\mathrm{k})$ product liability claims; both PMA and $510(\mathrm{k})$ cases should be analyzed using the standard in Riegel.

When taken together, the current $510(\mathrm{k})$ system is unlike that in place at the time of Lohr. In Lohr, no evidence of safety and effectiveness was required for the Model 4011 Lead. Medical devices manufacturers now must produce such evidence demonstrating a finding of safety and effectiveness that is then reviewed by the FDA. ${ }^{229}$ The FDA has the authority to impose new special controls over $510(\mathrm{k})$ products to provide reasonable assurance of safety and effectiveness even if there are identical predicates. The FDA has demonstrated that it is making this determination of safety and effectiveness and has the authority to impose safety requirements, thereby preempting any sort of alternative, state-based claim.

227. Rosecrans, supra note 209 , at 41.

228. The actual statutory standard for permitting a medical device is that "there is reasonable assurance of the safety and effectiveness" of the device. 21 U.S.C. $§ 393(b)(2)(C)$ (2006). This standard applies to all medical device classes. The statute does not require absolute safety. Rather, products are reviewed on a risk/benefit basis. If the benefits outweigh the risks, the product should be approved or cleared. 21 U.S.C. § 360c(a)(2) (2006).

229. 21 C.F.R. $\S 807.92$ (detailing all that is required for a device manufacturer to submit in their $510(\mathrm{k})$ summary). 


\section{FDA's Assessment of the 510(k) System Deserves Deference}

The statutory provisions creating the $510(\mathrm{k})$ system may, at first blush, appear confusing and obtuse. Because the current $510(\mathrm{k})$ system is the result of numerous statutory changes over thirty-five years, it can be difficult to easily understand. In fact, the actual words of $\S 510(\mathrm{k})$ seem to have little to do with the system that is actually in place. ${ }^{230}$ However, as shown above, when analyzed in detail, the $510(\mathrm{k})$ system clearly addresses device safety and effectiveness.

However, if one concludes that the statutory language is not completely clear or is otherwise ambiguous in some way, the FDA's interpretation of the statute must be given substantial deference. The agency is the expert and is charged by Congress with implementing the statutory provisions and mission. Unless unreasonable, long settled Supreme Court precedent mandates that the FDA's statements regarding the legal schema established through the $510(\mathrm{k})$ system, which makes safety and effectiveness determinations, must be accepted.231 This is particularly true given the consistency of the Agency's implementation of the $510(\mathrm{k})$ system and the alignment of the agency's interpretation and implementation with its congressionally mandated mission.

The FDA's interpretation that the post-1990 510(k) system does assess safety and effectiveness is bolstered by Congressional action (and inaction) since 1990. Lohr was decided in 1996. If the agency or Congress believed that the post- 1990 $510(\mathrm{k})$ system ignored device safety, it would be amazing if they did not change the system. Is it logical that Congress and the FDA would permit literally tens of thousands of medical devices requiring $510(\mathrm{k})$ review to be marketed without a safety and effectiveness assessment? It seems highly unlikely. And remember that Congress has made various changes to the medical device statutes since Lohr. In fact, the year after Lohr was decided, Congress made a number of highly substantive chang-

230. One can debate whether we should call this the 513(i) system rather than the 510(k) system. See supra note 202 and accompanying text. However, for historical reasons, everyone, including Congress, refers to this as the $510(\mathrm{k})$ system.

231. See generally Chevron, U.S.A., Inc. v. Natural Res. Def. Council, Inc., 467 U.S. 837 (1984) (setting forth the standard for when to grant deference to a federal agency's interpretation of a statute the agency is responsible for administering). 
es to the medical device provisions when it enacted the FDA Modernization Act (FDAMA). ${ }^{232}$ This would have been the perfect time to add safety and effectiveness requirements to the $510(\mathrm{k})$ system if such provisions were lacking.

Unless one believes that Congress either did not notice the Lohr decision or did not want medium risk devices assessed for safety and effectiveness, the only logical explanation as to why Congress or the FDA didn't change-or even try to change-the core $510(\mathrm{k}) /$ substantial equivalence/special controls approach to $510(\mathrm{k})$ device regulation is that Congress already addressed those issues with the 1990 SMDA.

Congressional action and the deference given to an agency's interpretation of its enabling statutes provide strong support for a conclusion that the $510(\mathrm{k})$ system does assess safety and effectiveness and that Lohr is not blindly applicable to products cleared under today's $510(\mathrm{k})$ system.

\section{E. Certain (BUt Certainly Not All) Third Parties Also Believe 510(K) CleARANCES UNDERGO A SAFETY AND EFFECTIVENESS ASSESSMENT.}

A number of third parties have opined, in one form or another, on whether the $510(\mathrm{k})$ system as currently enacted by Congress gives the FDA the authority to consider safety and effectiveness in making $510(\mathrm{k})$ decisions. Many of these third parties have referenced the role of the FDA as providing reasonable assurance of the safety and effectiveness of $510(\mathrm{k})$ cleared products. A number of others have made very different and contrary statements. ${ }^{233}$

In assessing these statements or positions, it is imperative to separate views on the authority Congress has given to the FDA from issues or disagreements with the FDA's use of that authority in the implementation of the $510(\mathrm{k})$ program. Authority issues are the key preemption question-if the Agency does not have the authority to regulate safety and effectiveness of a medical device, then there is no preemption given the language and requirements of $\S 360(\mathrm{k}) .{ }^{234}$ If the FDA has the authority to

232. See discussion supra Part II.A.3.

233. One must consider factors such as the potential biases of these third parties, their expertise, and the robustness of the review they performed before deciding what weight to give to any such positions.

234. Lohr itself is the classic example of this difference between authority and implementation questions. Medtronic, Inc. v. Lohr, 518 U.S. 470 (1996). In Lohr, the Court found that the FDA did not have the statutory authority to 
require whatever the plaintiff believes should have been done, but simply did not do so for whatever reason, there is preemption. Implementation problems or disagreements are not relevant to preemption. ${ }^{235}$ One might believe that the FDA made a mistake, missed some problem, or should have added a warning to a product. However, the FDA preemption is explicitly designed to ensure that the agency-not a state court jurymakes those decisions. Many criticisms from all sides address implementation issues, not authority issues, and therefore are not relevant to preemption issues.

While this article is not intended to present a detailed review of the secondary literature surrounding the actual implementation of the $510(\mathrm{k})$ system, several examples on both sides of the question may be of interest.

\section{Institute of Medicine Is Critical of the 510(k) System}

One of the most publicized criticisms of the $510(\mathrm{k})$ system came from an Institute of Medicine (IOM) ${ }^{236}$ report issued in July 2011. ${ }^{237}$ The IOM was commissioned by the FDA to conduct an analysis of the $510(\mathrm{k})$ regulatory scheme. ${ }^{238}$ In addition

make safety and effectiveness decisions. Id. at 493-94. The Court's decision in this preemption case was based on the lack of authority to create safety and effectiveness requirements, not whether the agency has wisely used that authority or made correct decisions. Id. at 502. In Riegel, the Court found that the FDA did have such authority so preemption was appropriate under $\S 360 \mathrm{k}$ whether or not the court agreed with the FDA's decision. Riegel v. Medtronic, Inc., 552 U.S. 312, 330 (2008).

235. Implementation problems are to be addressed by Congress, the agency, or the political process, not by state courts. See David M. Gossett, Chevron, Take Two: Deference to Revised Agency Interpretations of Statutes, 64 U. CHI. L. REV. 681 (1997).

236. The IOM is part of the National Academies of Science and is intended to provide "authoritative advice to decision makers." About the IOM, INST. MED. NAT'L ACADS., http://www.iom.edu/About-IOM.aspx (last updated Jan. $18,2012)$. The FDA asked the IOM to review the $510(\mathrm{k})$ clearance process for medical devices. See October Report, supra note 15, at 12.

237. Inst. OF MED. OF THE NAT'L ACADS., MEDICAL DEviCES AND PUBLIC'S Health: The FDA 510(K) Clearance Process at 35 Years (2011) [hereinafter IOM FINAL REPORT], available at http://www.iom.edu/Reports/2011/Medical-Devices-and-the-Publics-Health-

The-FDA-510k-Clearance-Process-at-35-Years.aspx.

238. One of the authors of this paper has written several articles asserting that the government is statutorily prohibited from relying on any report from the IOM $510(\mathrm{k})$ committee (regardless of its conclusions) because the IOM committee failed to have fair balance and representation from all stakeholders as required by $\S 15$ of the Federal Advisory Committee Act. Ralph Hall \& Eva 
to its final report in July 2011, the IOM released several "Workshop Reports" detailing the FDA's 510(k) clearance process during the course of their study. ${ }^{239}$ The output of the IOM committee presents two, somewhat conflicting, pictures of the $510(\mathrm{k})$ system.

In the IOM's October 2010 Report, the IOM stated that a safety and effectiveness determination is conducted prior to clearance of $510(\mathrm{k})$ medical devices. The IOM pointedly and correctly asserted that the same definitions of safe and efficacious apply to every medical device; the difference lies in how safety and effectiveness are determined for the specific device. ${ }^{240}$ The October Report sets forth how the FDA's governing statutes establish safety and effectiveness, largely through the submission of data, special controls, and product classification systems. ${ }^{241}$ Conversely, in its final report, the IOM stated that "[t]he $510(\mathrm{k})$ clearance process is not intended to evaluate the safety and effectiveness of medical devices with some exceptions." 242 IOM supports this conclusion, in part, by relying on Lohr-but without making the reassessment of that case as is done in this article. ${ }^{243}$

More interestingly - and not apparent from the IOM headline-the IOM's major criticism is not that the $510(\mathrm{k})$ system does not make a safety and effectiveness determination when reviewing a product, but rather the IOM is critical of the basis for the safety and effectiveness determination. Right after its conclusory statement referenced above, the IOM says "when the FDA finds a device substantially equivalent to a predicate device ... it has done no more than find that the new device is

Svensvad, A Failure to Comply: An Initial Assessment of Gaps in IOM's Medical Device Study Committee, 12 MinN. J.L. SCI. \& TECH. 731 (2011); Ralph Hall \& Eva Svensvad, Left to Their Own Devices: IOM's Medical Device Committee's Failure to Comply, 13 MINN. J. L. SCI. \& TECH. 91 (2012); see also Federal Advisory Committee Act (FACA), 5 U.S.C. app. 2 § 15 (2006).

239. See, e.g., October Report, supra note 15, at 2.

240. Id. at 8 (defining safety as the benefits of the medical device outweighing the risks and defining effectiveness as device producing significant results in a considerable portion of the intended population).

241. Id. at 11 .

242. IOM FINAL REPORT, supra note 237, at 5. Even if one accepts the IOM conclusion without any analysis, that conclusion requires that preemption in $510(\mathrm{k})$ cases exists in at least some cases. The IOM states that there are some cases in which the $510(\mathrm{k})$ system does conduct a safety and effectiveness determination.

243. The IOM repeats this conclusion at various places throughout the report using essentially the same reasoning and analysis. See, e.g., id. at 193. 
as safe and effective as the predicate." 244 So as even the IOM agrees, the FDA makes a safety and effectiveness determination-it is just that the IOM disagrees with the criteria for that assessment. ${ }^{245}$

Even taking the IOM's statement as true (something which many contest), the IOM is simply disagreeing with the criteria or method used by the FDA to make a safety and effectiveness determination. The fact that, as even the IOM concedes, the FDA makes a safety and effectiveness determination and has the express authority to impose special controls or data requirements is why $\S 360 \mathrm{k}$ is applicable to $510(\mathrm{k})$ products cleared under the current regulatory system.

The IOM also acknowledges that the medical device system uses data to determine the proper classification of the deviceClass I, II, or III-that will ensure its safety and effectiveness. ${ }^{246}$ The decision to place a device in a particular regulatory class is a finding that the device's safety and effectiveness will be properly maintained under the regulatory controls the class imposes. Thus, the FDA has made a safety and effectiveness determination that the $510(\mathrm{k})$ system provides an adequate assurance of safety and effectiveness for that product if the device is determined to be substantially equivalent. This determination is made prior to the first market distribution of a product of that type. This process demonstrates the FDA's focus on the safety and effectiveness of $510(\mathrm{k})$ devices. ${ }^{247}$

The IOM may or may not be correct in its conclusion that the $510(\mathrm{k})$ system is insufficient and should be "junked," and we note that the FDA immediately rejected the IOM's call to

244. Id. at $5-6$.

245. As an aside, generic drugs generally are required to show that they are as safe and effective as the reference drug. This is the same philosophical approach to regulation of new products as that which the IOM criticized in its view of how the $510(\mathrm{k})$ uses predicates. As noted elsewhere, generic drug lawsuits are subject to preemption as set forth in cases such as Mensing. See Section II.E. supra.

246. IOM FINAL REPORT, supra note 237, at $12-13$. The accompanying scientific data demonstrates the safety and effectiveness of the device, allowing the FDA to appropriately place the device under the regulatory controls that will further the safety and effectiveness of the device.

247. October Report, supra note 15, at 11-12 (finding, in addition, that any change in the device that may affect its safety and effectiveness requires the manufacturer to submit additional data and "obtain a new clearance from the FDA"). This allows the FDA to verify that 510K devices on the market remain safe and effective for public use. 
"junk" the $510(\mathrm{k})$ system. ${ }^{248}$ That argument is for the agency and Congress. The fact that, as even the IOM agrees, the $510(\mathrm{k})$ process determines that the device in question is "as safe as" the predicate, that the device in question raises no new questions of safety and effectiveness, and that the 510(k) system provides a reasonable assurance of safety and effectiveness is a safety determination outside of the authority of a state court jury to overthrow.

\section{Industry Views}

While industry's views on the $510(\mathrm{k})$ system must be assessed with consideration of the source, industry knows the $510(\mathrm{k})$ system inside and out. Industry universally supports the conclusion that the $510(\mathrm{k})$ system is intended by Congress and the FDA to provide a "reasonable assurance of safety and effectiveness." 249

Advanced Medical Technology Association (AdvaMed) is a prominent player in the medical device industry and is deeply involved in the $510(\mathrm{k})$ regulatory process. ${ }^{250}$ AdvaMed concludes, "data on device safety and use" is always collected in $510(\mathrm{k})$ submissions. ${ }^{251}$ Ultimately, AdvaMed believes that the $510(\mathrm{k})$ process is "one of many regulatory controls FDA has in place to ensure the safety and effectiveness of medical devices, regardless of their path to market." 252

The California Healthcare Institute (CHI) ${ }^{253}$ also affirms

248. Press Release, Food \& Drug Admin., FDA to Seek Public Comment on IOM Recommendations (July 29, 2011), available at http://www.fda.gov/NewsEvents/Newsroom/PressAnnouncements/ucm265908. htm.

249. October Report, supra note 15, at 9.

250. What We Do, ADVAMED, http://www.advamed.org/MemberPortal/ (last visited Apr. 12, 2012). AdvaMed is a trade association for medical device companies. Id.

251. AdvaMed, The 510(K) Process: The Key to Effective Device REGULATION 19 (2008), available at http://www.onlinetmd.com/FileUploads/file/AdvaMed_510K_White_Paper.pdf (emphasis added) (clarifying that "[t]his [data] provides FDA with information on actual, clinical use of well-characterized medical devices on which to base regulatory decisions"- the regulatory decisions that will continue to assure the determined safety and effectiveness of the device as demonstrated by the collected data).

252. Id. at 22 (emphasis added) (noting that "[i]t is important for patients to know that devices cleared via the $510(\mathrm{k})$ process undergo thorough FDA review" allowing the FDA to make sure devices are safe and effective).

253. California Heath Institute is "[a] public policy research and advocacy organization for California's biomedical industry." California Healthcare Insti- 
the FDA's assurance of safe and effective devices through the $510(\mathrm{k})$ clearance process. In reaching this conclusion, the CHI relies heavily on the FDA's increased requirements and emphasis on assuring safety to support the CHI's belief that $510(\mathrm{k})$ medical devices that are determined to be substantially equivalent are found safe and effective prior to market distribution. ${ }^{254}$ As support, the CHI also cites empirical data demonstrating the safety and effectiveness of cleared devices. In particular, the CHI notes that 510(k) devices, are subject to Class I recalls-recalls that present the most risk-at the same rate as PMA devices. ${ }^{255}$ AdvaMed and the CHI support the FDA's conclusion that the $510(\mathrm{k})$ process is clearing devices that the FDA has found to be safe and effective to market.

\section{Other Critics and Voices}

Without doubt, the $510(\mathrm{k})$ system has been subject to criticism from certain advocacy and medical groups. For example, Public Citizen has been critical of the 510(k) system for not providing enough safety protection. In fact, Public Citizen supported the IOM's call for a new system to replace the 510(k) system. ${ }^{256}$ The concerns raised by Public Citizen focus on the use of the "substantial equivalence" test for safety and effectiveness, the perceived lack of human clinical studies prior to clearance of a number of $510(\mathrm{k}) \mathrm{s}$, and the view that the system was not appropriately balancing safety with patient access to

tute: Organizational Profile, CHI, http://www.chi.org/industry/ IndustryDetails.aspx?ID=5273 (last visited Mar. 26, 2012).

254. See Cal. Healthcare Inst., Upcoming Changes to the 510K Process: New Approval Pathways and the ImpaCt on Medical DeVice AND DEVELOPMENT AND INNOVATION (2010), available at http://www.chi.org/uploadedFiles/Industry_at_a_glance/CHI-510K-White-

Paper-FINAL.pdf.

255. Id. at 6.

256. See, e.g., Article in PLos Medicine on Breakdown of U.S. Device Review Process, PUB. CITIZEN (July 2012), http://www.citizen.org/hrg1912; Statement of Dr. Michael Carome, Deputy Dir., Pub. Citizen's Health Research Group, Public Citizen Applauds IOM's Findings and Recommendations on 510(K) Medical Device Clearance Process (July 29, 2011), available at http://www.citizen.org/pressroom/pressroomredirect.cfm?ID=3393. It must be noted that a long time Public Citizen litigation attorney and head of that group for a number of years was a contributor to this article and also served on the IOM 510(k) committee. It appears that he continues to serve in an of counsel role with Public Citizen. See Michael Carome, M.D. Deputy Director, Health Research Group, PUB. CITIZEN, http://www.citizen.org/ Page.aspx?pid=5140 (last visited Mar. 5, 2012). 
new or improved products.

Several medical journals and medical societies have also published articles or otherwise opined on the robustness of the $510(\mathrm{k})$ system. Some of these are critical and make the same points expressed by Public Citizen. Some assert that the 510(k) system is allowing an excessive number of unsafe products onto the market. In addition to challenging the basic premises underlying the $510(\mathrm{k})$ system, these articles also question the FDA's implementation of the statutory authority provided by Congress.

The medical community has differing view on this issue. Others in the medical community have expressed support for the $510(\mathrm{k})$ system based on the view that the $510(\mathrm{k})$ system provides the agency with the authority to balance safety concerns with patient access to valuable new medical therapies. ${ }^{257}$ Regardless of whether one agrees or disagrees with these various positions, many of their stated concerns relate to implementation differences not authority issues.

\section{F. ReCEnT 510(K) Clearances Demonstrate an Assessment OF SAFETY AND EFFECTIVENESS}

One of the best tests for whether the $510(\mathrm{k})$ system in fact assesses safety and effectiveness is to look at how the system is actually implemented. To do so, one can review recent $510(\mathrm{k})$ clearances of actual medical devices. When one does so, one clearly sees that in actual $510(\mathrm{k})$ clearances the FDA repeatedly references its review of safety and effectiveness data and that cleared products meet the statutory requirement for a reasonable assurance of safety and effectiveness.

When a device manufacturer submits a $510(\mathrm{k})$ summaryinstead of making the $510(\mathrm{k})$ statement-for the $510(\mathrm{k})$ for their device, the summary must include a basis for the FDA to conclude substantial equivalence. ${ }^{258}$ As discussed in section III, D.1, the manufacturer must include a "brief discussion of the clinical tests submitted ... [that] include[s] . . a discussion of the safety and effectiveness data[.]"259 Recent devices deter-

257. See, for example, the position of the American Academy of Orthopaedic Surgeons questioning whether there is actually a systemic problem with the 510(k) system. William M. Mihalko et al., The 510(k) Process-It's Not Broken, so Why "Fix" it?, AM. ACAD. ORTHOPEDIC SURGEONS (Oct. 2010), http://www.aaos.org/news/aaosnow/oct10/cover2.asp.

258. 21 C.F.R. $\$ 807.92$ (2011).

259. Id. Further, for a device to gain clearance, the tests must demonstrate 
mined substantially equivalent under $510(\mathrm{k})$, coupled with their $510(\mathrm{k})$ summary demonstrate that FDA does, in fact, make safety and effectiveness assessments in making $510(\mathrm{k})$ product clearance decisions.

Via Biomedical, Inc.'s Stent Graft Balloon Catheter was determined substantially equivalent and cleared for market distribution in 2009. ${ }^{260}$ Included in the 510(k) summary was the following:

The Stent Graft Balloon Catheter underwent mechanical, performance, and biocompatibility testing to verify that the device functions in a safe and effective manner. The results of the tests provide reasonable assurance that the device has been designed and tested to assure conformance to the requirements for its indications for use. ${ }^{261}$

In accepting Via Biomedical's 510(k) summary and clearing the catheter for market, FDA acknowledged and confirmed the devices substantial equivalence for the indications determined safe and effective in the proceeding summary. 262

Becton, Dickinson and Company's (Becton) BD Flu+ Syringe was cleared for marketing on July 2, 2009. As part of the requisite basis the manufacturer must submit, Becton expressly indicated that "[d] esign [v]erification tests were performed based on the risk analysis performed, and the results of these tests demonstrate that the BD Flu + Syringe performed in an equivalent manner to the predicate device and is safe and effective when used as intended."263 The FDA similarly cleared the BD Flu + Syringe for its intended use-the specific use for which Becton determined. In doing so, the FDA confirmed the finding of safety and effectiveness for the BD Flu + Syringe.

Likewise, ArthoCare's Bone Cement Opacifier was cleared under 510(k) after the FDA confirmed that "[t]he performance testing and device comparison demonstrated that the subject device [was] substantially equivalent to the predicate device,

that "the device is as safe, as effective, and performs as well as or better than the [predicate] device...." Id.

260. 510K Summary from Via Biomedical, Inc. on the Stent Graft Balloon Catheter, ACCESSDATA (May 29, 2009), http://www.accessdata.fda.gov/ cdrh_docs/pdf9/K091624.pdf.

261. Id. (emphasis added).

262. See id.

263. 510K Summary of Safety and Effectiveness from Becton, Dickinson and Company on the BD Flu+ Syringe, ACCESSDATA (July 2, 2009), http://www.accessdata.fda.gov/cdrh_docs/pdf9/K091377.pdf. 
and is safe and effective for its intended use."264

Other examples of $510(\mathrm{k})$ devices-Master Healthcare's Easy Touch Insulin Syringe, ${ }^{265}$ ZOLL Circulation's Central Venous Catheter and Thermal Regulating System ${ }^{266}$ and Medtronic's Cardiopulmonary Centrifugal Blood Pump267-all included performance data specifically relating to and determining the safety and effectiveness of the device as part of the "basis" for $510(\mathrm{k})$ clearance.

Actual $510(\mathrm{k})$ clearances repeatedly reference safety and effectiveness determinations. The real life implementation of the 510(k) system confirms that Congress created and the FDA implemented a system that specifically includes safety and effectiveness determinations.

\section{G. What Does a SAFETy AND EFFECTIVEnESs DETERMination MEAN FOR LOHR?}

The Supreme Court found that the product liability claims in Lohr were not preempted based on the Court's conclusion that under the $1982510(\mathrm{k})$ system the FDA never made and did not have the authority to make a safety and effectiveness determination for the Model 4011 lead. The Court also found that the 1982 501(k) system did not create any device specific safety and effectiveness requirements applicable to the Model 4011 lead. The Court left open the question of preemption for PMA devices-a question the Court answered in the affirmative a few years later in Riegel. The Court found preemption in Riegel because the FDA does make a safety and effectiveness finding for PMA products.

When applying current preemption doctrine to the 510(k) system, one can see that all of the relevant substantive ele-

264. 510K Summary from ArthroCare on the Bone Cement Opacifier, ACCESSDATA (Dec. 27, 2004), http://www.accessdata.fda.gov/cdrh_docs/ pdf4/K042947.pdf (emphasis added). The device was not found to be as safe as the predicate, but there was an independent assessment. Id. The device was both substantially equivalent to the predicate as well safe and effective. $I d$.

265. 510K Summary from Masters Healthcare on the Easy Touch Insulin Syringe, ACCESSDATA (May 14, 2009) http://www.accessdata.fda.gov/ cdrh_docs/pdf9/K091474.pdf.

266. 510K Summary from ZOLL Circulation for Venous Catheter and Thermal Regulating System, ACCESSDATA (Oct. 12, 2010), http://www.accessdata.fda.gov/cdrh_docs/pdf10/K101987.pdf.

267. Summary of Safety and Effectiveness from Medtronic for the Cardiopulmonary Centrifugal Blood Pump, ACCESS DATA (June 21, 2010), http://www.accessdata.fda.gov/cdrh_docs/pdf10/K100631.pdf. 
ments of the PMA system found in Riegel to require preemption now exist in the $510(\mathrm{k})$ system. Specifically, one can ask whether the 510(k) system gives the FDA the authority to require data submission or the authority to impose safety requirements such as warnings or design requirements. The answer is yes. Under 21 U.S.C. § 360c(a), the FDA can implement special controls applicable to all Class II devices of a certain type. These special controls can include-as the FDA deems appropriateclinical data submissions, post market registries, design requirements, and labeling requirements. The FDA also has the authority to impose performance standards if such a standard "is necessary to provide reasonable assurance of the safety and effectiveness of the device."268 These various control mechanisms are specific to the device type and are, by statutory definition, ${ }^{269}$ not the general controls at issue in Lohr. If necessary, the FDA can even use general controls to ban unsafe 510(k) devices. $^{270}$

Of course, technology evolves and Congress has addressed that scenario as well. If the device has different technological characteristics compared to the predicate, the $510(\mathrm{k})$ sponsor must demonstrate that the device is still as safe and effectiveor they can be safer or more effective-as the predicate. ${ }^{271}$ Furthermore, companies cannot make safety-related changes to a $510(\mathrm{k})$ device without prior FDA clearance. ${ }^{272}$

The bottom line is that one is hard pressed to identify a premarket or post-market requirement applicable to the device that the FDA could not have imposed, had the FDA chosen to do so. This includes clinical data requirements, design requirements, and labeling requirements. While one might disagree with what the FDA did or did not do, the fact remains that FDA had the authority to do so. If the authority exists, preemption applies.

268. 21 U.S.C. $\S 360 d(a)(1)$ (2006). The FDA can also require compliance with recognized national or international standards such as ISO standards. 21 U.S.C. $\S 360 \mathrm{~d}(\mathrm{c})(1)(\mathrm{A})$.

269. Special controls are separately defined by statute and are to be used when general controls (the regulatory mechanism at issue in Lohr) are not sufficient to provide the reasonable assurance of safety required under the statute. See 21 U.S.C. § 360c(a)(1)(A) (2006) (definition of general controls) and 21 U.S.C. $\S 360 c(a)(1)(B)$ (definition of special controls).

270. 21 U.S.C. $\S 360 f(2006)$.

271. 21 U.S.C. $\$ 360 \mathrm{c}(\mathrm{i})(1)(\mathrm{A})(\mathrm{ii})$.

272. 21 C.F.R. $§ 807.81$ (a) (2011). 
As the above analysis demonstrates, the relevance of Lohr today is highly questionable in light of the current statutory framework and the FDA's present implementation of the 510(k) system. Today, the FDA makes safety and effectiveness determinations for $510(\mathrm{k})$ medical devices in determining the classification of the new device, compared to the predicate device, and whether the new device is substantially equivalent or not substantially equivalent. Due to this safety and effectiveness finding, and if the device is found to be substantially equivalent, product liability claims asserted against $510(\mathrm{k})$ devices may well actually impose additional or conflicting requirements relating to the "safety and effectiveness of a medical device" cleared under $510(\mathrm{k}) .{ }^{273}$

There are two core reasons for preemption in "modern" $510(\mathrm{k})$ cases. First, additional safety and effectiveness requirements are preempted under $\S 360 \mathrm{k}$ (a) of the FDCA, which disallows state standards "relat[ing] to the safety and effectiveness of the device." 274 Secondly, additional or different safety and effectiveness requirements at the state level hamper the central facet of the FDA mission: to balance safety, effectiveness, and access to medical devices and to foster innovation. Because a state court or jury can only address-and may well be more concerned with-individual safety, they are not in a position to balance the negative impacts of the additional or different requirements on other patients, do not have access to all of the information available to the FDA, and are compelled to impose additional or different safety requirements for medical devices. ${ }^{275}$

Riegel accurately describes the PMA process as a federal safety review, thereby pre-empting state claims relating to the

273. See 21 U.S.C. § 360k(a) (2006). The "parallel claim" exception set forth in Riegel would appear to be applicable to the $510(\mathrm{k})$-based product liability cases.

274. Id.; see also 21 C.F.R. § 808.1(d) (2010) (stressing that state requirements relating to safety and effectiveness are pre-empted when the FDA "has established specific counterpart regulations or there are other specific requirements applicable to a particular device"). The assessment of safety and effectiveness in the $510(\mathrm{k})$ clearance process establishes a "specific counterpart regulation" for that medical device.

275. A state is more concerned with issues at the individual level, and therefore, places greater emphasis on the safety of the device. The FDA, on the other hand, must consider the entirety of the nation and must ensure safety, yet also promote medical device innovation as well. See Brief for Petitioner at 16, Medtronic, Inc. v. Lohr, 518 U.S. 470 (1996) (Nos. 95-754, 95-886), 1996 WL 88789. 
safety or effectiveness of the medical device.276 The FDA now has the authority to impose safety requirements on $510(\mathrm{k})$ devices, conduct a safety and effectiveness reviews for 510(k) devices, and as such, state claims imposing additional safety standards should similarly be pre-empted. Arguably, if Medtronic's Model 4011 Lead was cleared under today's statutory regime, a Court assessing a product liability suit against that Lead should find the claim preempted.

\section{CONCLUSION}

In this article, we make two fundamental points relating to preemption and $510(\mathrm{k})$ products. First, Lohr analyzed the $510(\mathrm{k})$ system as it existed thirty years ago. There have been material changes in the $510(\mathrm{k})$ system since that time. Statutory interpretation cases should not be blindly followed if there have been major changes in the statute since such decisions were issued. That is precisely the case with Lohr. Because the $510(\mathrm{k})$ system has changed so much in the last thirty years, Lohr must be reassessed. Second, a reassessment of Lohr based on the current $510(\mathrm{k})$ system and current preemption law leads to the conclusion that a $510(\mathrm{k})$ product cleared under the modern system may well be entitled to preemption.

The recent high level of attention on the $510(\mathrm{k})$ system has brought renewed focus to the system and demonstrated that, while perhaps not intuitive, the FDA has the authority to impose safety and effectiveness requirements on $510(\mathrm{k})$ products and that the modern $510(\mathrm{k})$ system does, in fact, make safety and effectiveness determinations. ${ }^{277}$ The system does this through the initial classification process, the power to impose

276. Riegel v. Medtronic, Inc., 552 U.S. 312, 312-13 (2008) (concluding that Mr. Riegel's defective device claims were pre-empted by $\S 360 \mathrm{k}$ (a) because the State's requirements held Medtronic's balloon catheter to a different safety standard than the requirements placed by the FDA).

277. The recent FDA controversy involving the 510(k) clearance and then withdrawal of ReGen Menaflex has brought into the limelight the lack of knowledge by many about the current $510(\mathrm{k})$ system. In a preliminary report of the ReGen Menaflex review, the FDA avowed: "[o]ur review identified multiple sources of disagreement and confusion about $510(\mathrm{k})$ standards and practices[.]" FoOD \& DRUG ADMin., REview OF THE REGEN MENAFlex: Departures From Processes, Procedures, And Practices Leave the BASIS FOR A REVIEW DECISION IN QUESTION 15 (2009), available at http://www.fda.gov/downloads/NewsEvents/PublicHealthFocus/UCM183642.p df. 
requirements through mechanisms such as "special controls," and then by the device-specific clearance decision-or nonclearance decision - under the "substantially equivalent" test.

While all agree that a $510(\mathrm{k})$ cleared device is "substantially equivalent" to a predicate, "substantial equivalence" is a term of art under the FDCA and implementing regulations. As such, it must be interpreted in light of how the statute defines and uses that term. Unlike prior "substantial equivalence" clearances, today's substantial equivalence includes a finding that the device is both safe and effective for its intended use. Not only does Congressional purpose and statutory framework surrounding $\S 360 \mathrm{c}$ establish the requirement of the safety and effectiveness for $510(\mathrm{k})$ devices, but the FDA as well as other persuasive authorities demonstrate that a safety and effectiveness determination is present in $510(\mathrm{k})$ decisions. This is shown through the express findings of safety and effectiveness documented in the device's clearance letter.

The standard applied in Lohr principally relied on the fact that the safety and effectiveness of the implanted lead were not accounted for prior to the device's clearance. This finding is now outdated and no longer applicable. The Court's finding in Riegel-in which product liability claims brought under state law are preempted due to FDA's authority to impose safety requirements and its prior determination of safety and effectiveness for the PMA device-should apply to 510(k) devices as well. 


\section{Appendix}

\begin{tabular}{|c|c|c|c|}
\hline \multicolumn{4}{|c|}{ Comparison of the 1976 statute with current statute. } \\
\hline & Current & 1976 & $\begin{array}{l}\text { Does Current } \\
\text { System Impose } \\
\text { More Safety or } \\
\text { Effectiveness } \\
\text { Requirements? }\end{array}$ \\
\hline $\begin{array}{l}\text { Requires the foregoing infor- } \\
\text { mation to be available before a } \\
\text { device can be classified as } \\
\text { Class II: } \\
\text { Promulgation of per- } \\
\text { formance standards; } \\
\text { Postmarket surveil- } \\
\text { lance; Patient regis- } \\
\text { tries; Development and } \\
\text { dissemination of guide- } \\
\text { lines (including guide- } \\
\text { lines for the submission } \\
\text { of clinical data in pre- } \\
\text { market notification } \\
\text { submissions in accord- } \\
\text { ance with 510(k)); and } \\
\text { Recommendations, and } \\
\text { other appropriate ac- } \\
\text { tions as the Section } \\
\text { deems necessary to } \\
\text { provide such assurance. } \\
\text { If not available, classi- } \\
\text { fied in Class III }\end{array}$ & $\begin{array}{l}360 c(a)( \\
B) \text { and } \\
(\mathrm{C})(\mathrm{i})(\mathrm{II})\end{array}$ & $\begin{array}{l}513(\mathrm{a})(\mathrm{B}) \\
\text { Only re- } \\
\text { quired } \\
\text { that } \\
\text { there be } \\
\text { "suffi- } \\
\text { cient in- } \\
\text { formation } \\
\text { to estab- } \\
\text { lish a } \\
\text { perfor- } \\
\text { mance } \\
\text { stand- } \\
\text { ard" }\end{array}$ & Yes \\
\hline $\begin{array}{l}\text { The Secretary shall consider } \\
\text { whether the extent of data that } \\
\text { otherwise would be required for } \\
\text { approval of the application with } \\
\text { respect to effectiveness can be } \\
\text { reduced through reliance on } \\
\text { postmarket controls. }\end{array}$ & $\begin{array}{l}360 c(a) \\
(3)(C)\end{array}$ & $\begin{array}{l}\text { Not in } \\
1976 \\
\text { statute }\end{array}$ & Indirectly \\
\hline $\begin{array}{l}\text { The Secretary, upon written re- } \\
\text { quest, shall meet with a person } \\
\text { intending to submit application } \\
\text { under } \S 360 \text { e and determine the } \\
\text { type of scientific evidence neces- } \\
\text { sary to demonstrate device's ef- } \\
\text { fectiveness. }\end{array}$ & $\begin{array}{l}360 c(a) \\
(3)(D)(i)\end{array}$ & $\begin{array}{l}\text { Not in } \\
1976 \\
\text { statute }\end{array}$ & Indirectly \\
\hline $\begin{array}{l}\text { Any clinical data, including one } \\
\text { or more well-controlled investi- } \\
\text { gations, specified in writing by } \\
\text { the Secretary for demonstrating } \\
\text { a reasonable assurance of device }\end{array}$ & $\begin{array}{l}360 c(a) \\
\text { (3)(D)(ii) }\end{array}$ & $\begin{array}{l}\text { Not in } \\
1976 \\
\text { statute }\end{array}$ & Yes \\
\hline
\end{tabular}




\begin{tabular}{|c|c|c|c|}
\hline $\begin{array}{l}\text { effectiveness shall be specified } \\
\text { as result of a determination by } \\
\text { the Secretary that such data are } \\
\text { necessary to establish device } \\
\text { effectiveness. }\end{array}$ & & & \\
\hline $\begin{array}{l}\text { The Secretary may initiate the } \\
\text { reclassification of a device clas- } \\
\text { sified into Class III, or the man- } \\
\text { ufacturer or importer of a device } \\
\text { classified under paragraph (1) } \\
\text { may petition the Secretary for } \\
\text { the issuance of an order classify- } \\
\text { ing the device in Class I or } \\
\text { Class II. }\end{array}$ & $\begin{array}{l}360 \mathrm{c}(\mathrm{f}) \\
(3)(\mathrm{A})\end{array}$ & $\begin{array}{l}\text { Not in } \\
1976 \\
\text { statute }\end{array}$ & Yes \\
\hline $\begin{array}{l}\text { Upon determining that a peti- } \\
\text { tion does not contain any defi- } \\
\text { ciency, the Secretary may refer } \\
\text { the petition to an appropriate } \\
\text { panel to make a recommenda- } \\
\text { tion to the Secretary respecting } \\
\text { approval or denial of the peti- } \\
\text { tion. A recommendation shall } \\
\text { contain: } \\
\text { a summary of the rea- } \\
\text { sons for the recommen- } \\
\text { dation; } \\
\text { a summary of the data } \\
\text { upon which the recom- } \\
\text { mendation is based; } \\
\text { and } \\
\text { an identification of the } \\
\text { risks to health (if any) } \\
\text { presented by the device } \\
\text { with respect to which } \\
\text { the petition was filed. } \\
\text { In the case of a petition for a } \\
\text { device which is intended to be } \\
\text { implanted in the human body or } \\
\text { which is purported or represent- } \\
\text { ed to be for a use in supporting } \\
\text { or sustaining human life, the } \\
\text { panel shall recommend that the } \\
\text { petition be denied unless the } \\
\text { panel determines that the clas- } \\
\text { sification in Class III of the de- } \\
\text { vice is not necessary to provide } \\
\text { reasonable assurance of its safe- } \\
\text { ty and effectiveness. }\end{array}$ & $\begin{array}{l}360 \mathrm{c}(\mathrm{f}) \\
(3)(\mathrm{B})(\mathrm{i})\end{array}$ & $\begin{array}{l}\text { Not in } \\
1976 \\
\text { statute }\end{array}$ & Yes \\
\hline
\end{tabular}

